\title{
Model Sistem Hitung Kendaraan pada Area Parkir Bertingkat 2 Menggunakan Mikrokontroler ATMega8535
}

\author{
Wiwik Dwi Agustin ${ }^{1}$, Emir Nasrullah $^{2}$, Raden Arum Setia Priadi ${ }^{3}$ \\ Jurusan Teknik Elektro Universitas Lampung, Bandar Lampung \\ J1. Prof. Sumantri Brojonegoro No.1 Bandar Lampung, 35145
}

Intisari - Area parkir dalam kehidupan sehari-hari sangat dibutuhkan oleh masyarakat, apalagi di daerah perkotaan. Berlatar belakang kebutuhan akan efisiensi waktu dan bahan bakar kendaraan serta pengembangan teknologi otomasi, maka melalui penelitian ini telah dirancang sebuah piranti yang bertujuan untuk menginformasikan kepada pengemudi apakah dapat memarkir kendaraannya atau tidak pada suatu area parkir dan diharapkan bermanfaat menghemat waktu dan bahan bakar kendaraan. Apabila area parkir terisi penuh oleh kendaraan yang parkir, motor servo akan berputar dan palang pintu yang terhubung akan menutup sehingga kendaraan tidak dapat masuk ke area parkir yang penuh.Model sistem hitung kendaraan pada area parkir bertingkat 2 pada tugas akhir ini pada intinya merupakan piranti dengan miktrokontroler sebagai pengendali utama yang terhubung dengan sensor ultrasonik sehingga dapat memindai masuk dan keluar kendaraan roda empat (mobil) pada suatu area parkir serta memberikan informasi jumlah lahan parkir yang belum terisi melalui LCD yang terpasang pada pintu masuk, sehingga memudahkan pengendara mobil untuk memutuskan apakah perlu memasuki area parkir tersebut untuk memarkir kendaraannya atau mencari tempat parkir lain tanpa harus berputar-putar pada area parkir tersebut sehingga memakan waktu dan bahan bakar kendaraan. Apabila kondisi area parkir telah terisi penuh oleh kendaraan, maka terdapat motor servo yang terhubung dengan palang pintu yang akan menutup akses masuknya kendaraan sehingga kendaraan tidak dapat memasuki area parkir.Tugas akhir ini mengimplementasikan perancangan sebuah model sistem hitung kendaraan secara otomatis yang dapat menginformasikan kepada pengendara apakah dapat memarkir kendaraannya atau tidak pada suatu area parkir. Selain itu diharapkan dapat diimplementasikan langsung pada suatu area parkir bertingkat.

Kata kunci - Mikrokontroler, Sensor ultrasonik, LCD, Motor servo.

Abstract - Parking lot is needed by society everyday, especially in urban areas. Background of the need for time efficiency and vehicle fuel and the development of automation technology, then this research has designed a tool that aims to inform the driver whether the vehicle may be parked or not in a parking area and is expected to be useful to save time and fuel vehicles. If the condition of parking areas have filled with vehicles, the servo motor is connected to the cross bar that would close access to the entry of vehicles so that vehicles can not enter the parking area. Model of the vehicle counting system at the 2-floors parking garage at the end of this task is essentially a tool to microcontroller as main controller connected to the ultrasonic sensor that can scan incoming and outgoing four-wheeled vehicles (cars) at a parking area and provide information of ample parking not filled through the LCD attached to the entrance, making it easier for driver to decide whether to enter the parking area to park the vehicle or to find another parking space without spinning the parking area so that it takes time and fuel vehicles. This final task of implementing the design of a counting system model vehicles can automatically inform the driver whether the vehicle may be parked or not in a parking lot. Also expected to be implemented directly on a multilevel parking area.

Keywords - Microcontroller, Ultrasonic sensor, LCD, Servo motor, Parking lot. 


\section{PENDAHULUAN}

Sistem kendali telah memegang peranan yang sangat penting dalam perkembangan ilmu dan teknologi. Kebutuhan manusia yang meningkat memicu perkembangan teknologi. Untuk membantu memenuhi kebutuhan tersebut saat ini mulai dikembangkan teknologi di bidang robot untuk membantu dalam melaksanakan tugas tertentu. Untuk dapat diklasifikasikan sebagai robot, mesin harus memiliki dua macam kemampuan yaitu bisa mendapatkan informasi dari sekelilingnya dan bisa melakukan sesuatu secara fisik seperti bergerak atau memanipulasi objek. Untuk dapat dikatakan sebagai robot sebuah sistem tidak perlu untuk meniru semua tingkah laku manusia, namun suatu sistem tersebut dapat mengadopsi satu atau dua saja sistem yang ada pada diri manusia sudah dapat dikatakan sebagai robot. Sistem yang diadopsi mesin tersebut berupa sistem penglihatan (mata), sistem pendengaran (telinga) ataupun sistem gerak.

Sistem parkir kendaraan khususnya sistem parkir mobil roda empat yang tersedia pada saat ini sebagian besar masih menggunakan tenaga manusia sebagai penjaga pintu dan area parkir. Hal ini tidak efisien mengingat mobil yang ada semakin banyak sedangkan area parkir tetap. Khususnya daerah ibukota, area parkir biasanya berada pada satu atau dua lantai yang paling dasar pada suatu gedung. Seringkali pengendara mobil berputar-putar pada setiap area parkir guna mencari tempat parkir untuk mobilnya, namun akhirnya kecewa karena tidak tersedianya tempat parkir bagi mobilnya dan harus mencari tempat parkir di lantai lain. Sangat tidak efisien, karena hal ini tentunya menyita waktu bagi pengendara dan menambah konsumsi bahan bakar bagi mobil.

Dengan perancangan sistem hitung kendaraan ini diharapkan akan menghasilkan model sistem hitung mobil pada area parkir secara otomatis yang dapat menghitung jumlah mobil pada area parkir sehingga palang pintu dapat menutup secara otomatis dan mobil tidak dapat masuk apabila area parkir penuh. Palang pintu tersebut tetap membuka apabila masih tersedia ruang untuk parkir.

\section{TINJAUAN PUSTAKA}

\section{A. Mikrokontroler ATMega 8535}

Mikrokontroler ATMega8535 adalah salah satu jenis mikrokontroler keluarga AVR dengan konsumsi daya rendah yang diproduksi oleh Atmel Corporation. ATMega8535 merupakan mikrokontroler 8 bit dengan arsitektur RISC (Reduce Instruction Set Computer).

Fitur-fitur yang dimiliki oleh mikrokontroler ATMega8535 antara lain:

1. Lebar data 8 bit.

2. Memiliki 130 buah instruksi.

3. Dapat mencapai kecepatan 16 MIPS (Mega Instruction per Second) pada frekuensi clock $16 \mathrm{MHz}$.

4. Memiliki 32 x 8 register aplikasi umum.

5. $8 \mathrm{k}$ byte flash memory untuk memori program .

6. 512 byte EEPROM untuk memori data nonvolatile.

7. 512 byte SRAM.

8. Dua 8 bit pewaktu/counter.

9. Satu 16 bit pewaktu/counter.

10. Empat saluran untuk penghasil sinyal $\mathrm{PWM} /$ clock.

11. 8 saluran, 10 bit ADC.

Mikrokontroler ATMega8535 dalam sistem yang akan dibuat digunakan sebagai pengendali utama sistem. Mikrokontroler ini menerima masukan dari sensor ultrasonik berupa data jarak benda yang terdeteksi. Data jarak benda tersebut akan diproses oleh mikrokontroler yang difungsikan sebagai counter. Keluaran dari mikrokontroler terhubung dengan motor servo standar yang berfungsi sebagai penggerak palang pintu, di mana palang pintu hanya akan menutup apabila counter menghitung jumlah mobil yang terdapat pada area parkir telah sama dengan angka referensi yang telah diatur dalam mikrokontroler. Angka referensi ini merupakan angka maksimal mobil yang dapat diparkir. Keluaran mikrokontroler juga terhubung dengan LCD yang akan menampilkan jumlah kendaraan yang dapat diparkir di kedua lantai.

\section{B. Sensor Ultrasonik}

Gelombang ultrasonik didefinisikan sebagai gelombang mekanik seperti gelombang suara dengan frekuensi yang melebihi batas dengar manusia yaitu lebih dari $20 \mathrm{kHz}$. Seperti jenis gelombang lainnya, gelombang ultrasonik juga merambat pada suatu medium dan bila mengenai suatu benda/obyek, maka sebagian gelombang akan dipantulkan, sebagian akan 
dilewatkan dan sebagian lagi akan diserap. Metode time of flight adalah metode menemukan jarak dengan memperoleh beda waktu antara gelombang ultrasonik sejak dipancarkan sampai gelombang pantul diterima pertama kali. Kelebihan dari metode ini adalah mudah untuk digunakan dan tidak ada kalibrasi frekuensi. Sedangkan kekurangan metode ini adalah tidak dapat mengukur jarak objek yang sudut pantulnya tidak sama dengan sudut datang. Sensor yang digunakan adalah Parallax Ping ultrasonic range finder di mana sensor ini menggunakan metode time of flight atau waktu yang dibutuhkan gelombang ultrasonik untuk melakukan perjalanan pergi dan kembali. Sensor ini memiliki unit kontrol yang mengatur kerja transduser ultrasonik, terdiri atas sebuah transduser ultrasonik transmitter yang berfungsi mengirimkan gelombang suara dengan frekuensi $40 \mathrm{kHz}$, dan sebuah transduser ultrasonik receiver yang berfungsi untuk menangkap pantulan gelombang suara yang dikirimkan oleh transduser ultrasonik transmitter.

Penggunaan gelombang ultrasonik dalam tugas akhir ini memanfaatkan kelebihannya sebagai berikut :

- Tidak mengganggu ketenangan manusia.

- Tidak dipengaruhi oleh cahaya.

- Cepat rambat gelombang tersebut dalam medium udara diketahui.

- Jika dipancarkan dan mengenai benda, maka permukaan benda tersebut akan memantulkan gema.

Sedangkan kekurangan gelombang ultrasonik adalah :

- Cepat rambat gelombang dalam medium dipengaruhi oleh suhu.

- Jarak yang ditempuh gelombang ultrasonik terbatas.

Sensor ultrasonik dalam sistem yang akan dibuat digunakan sebagai pemindai yang akan mendeteksi benda melintas, dalam hal ini benda yang melintas berupa mobil tamiya. Sensor terpasang pada setiap pintu. Pada sistem, terdapat dua pintu masuk dan dua pintu keluar.

\section{Motor Servo}

Motor servo memiliki tiga kabel. Kabel merah untuk suplai daya dengan besar tegangan berkisar 5 sampai 7 volt. Kabel putih merupakan kabel pengendali yang dapat langsung dihubungkan ke mikrokontroler. Posisi perputaran motor dapat dikendalikan dengan menggunakan gelombang pulsa yang dikirimkam ke motor servo. Untuk mengendalikan pergerakan motor digunakan metode PWM (Pulse Width Modulation). PWM merupakan suatu metoda untuk mengatur pergerakan motor dengan cara mengatur persentase lebar pulsa high terhadap periode dari suatu sinyal persegi dalam bentuk tegangan periodik yang diberikan ke motor. Motor servo akan dapat menerima pulsa setiap 20 ms. Panjang dari pulsa akan berpengaruh terhadap perputaran dari motor, sebagai contoh jika panjang pulsa $1,5 \mathrm{~ms}$, akan membuat motor berputar sebanyak $90^{\circ}$, jika lebar pulsa lebih besar dari $1.5 \mathrm{~ms}$, motor akan berputar mendekati $180^{\circ}$ sedangkan jika lebih kecil dari $1,5 \mathrm{~ms}$ motor akan berputar mendekati $0^{0}$. Motor servo dapat berputar sebanyak $90^{\circ}$ sampai $180^{\circ}$, selain itu ada juga yang dapat berputar $360^{\circ}$.

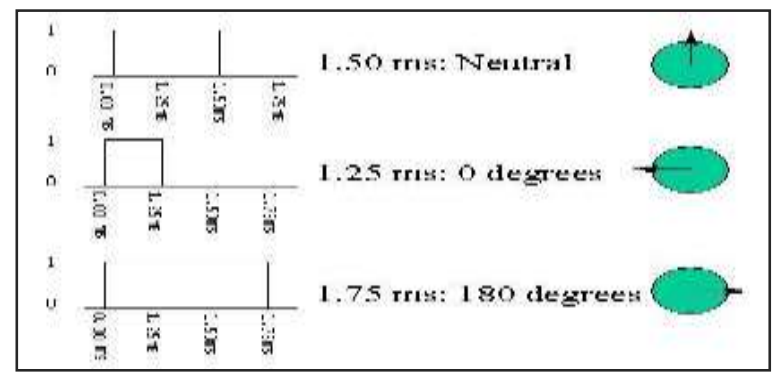

Gbr. 1 Derajat putaran motor servo standar.

\section{Liquid Crystal Display (LCD)}

Liquid Crystal Display adalah suatu perangkat elektronik yang dapat digunakan untuk menampilkan bilangan atau teks, merupakan kristal cair pada layar yang digunakan sebagai tampilan dengan memanfaatkan listrik untuk mengubah-ubah bentuk kristal-kristal cairnya sehingga membentuk tampilan angka dan atau huruf pada layar. Bila dibandingkan dengan rangkaian penampil lainnya yaitu seven segment, maka LCD mempunyai kelebihan yaitu dapat menampilkan karakter angka, huruf besar dan huruf kecil serta karakter-karakter tertentu.

LCD yang umum, ada yang panjangnya hingga 40 karakter $(2 \times 40$ dan $4 \times 40)$, di mana kita menggunakan DDRAM untuk mengatur tempat penyimpanan karakter tersebut. Alamat awal karakter $00 \mathrm{H}$ dan alamat akhir 39H. Jadi, alamat di baris kedua dimulai dari $40 \mathrm{H}$. Jika kita ingin meletakkan suatu karakter pada baris ke-2 kolom pertama, maka harus diatur pada alamat 40H. Jadi, meskipun LCD yang digunakan $2 \times 16$ atau $2 \times 24$ atau bahkan $2 \times 40$, maka penulisan programnya sama saja.

Liquid Crystal Display (LCD) bisa dikatakan sebagai modul penampil yang 
banyak digunakan karena tampilannya menarik. LCD yang paling banyak digunakan saat ini adalah LCD M1632 refurbish.

Tabel 1 Konfigurasi pin LCD

\begin{tabular}{|c|c|c|}
\hline No & $\begin{array}{c}\text { Nama } \\
\text { Pin }\end{array}$ & Deskripsi \\
\hline 1 & GND & 0V \\
\hline 2 & VCC & +5 \\
\hline 3 & VEE & Tegangan Kontras LCD \\
\hline 4 & R/S & $\begin{array}{c}\text { Register Select, 0 Register } \\
\text { Perintah, } 1=\text { Register Data }\end{array}$ \\
\hline 5 & R/W & $1=$ Read, $0=$ Write \\
\hline 6 & E & $\begin{array}{c}\text { Enable Clock LCD, Logika 1 } \\
\text { setiap kali pengiriman atau } \\
\text { pembacaan data }\end{array}$ \\
\hline 7 & D0 & Data Bus 0 \\
\hline 8 & D1 & Data Bus 1 \\
\hline 9 & D2 & Data Bus 2 \\
\hline 10 & D3 & Data Bus 3 \\
\hline 11 & D4 & Data Bus 4 \\
\hline 12 & D5 & Data Bus 5 \\
\hline 13 & D6 & Data Bus 6 \\
\hline 14 & D7 & Data Bus 7 \\
\hline 15 & Anoda & Tegangan Positif Backlight \\
\hline 16 & Katoda & Tegangan Negatif Backlight \\
\hline
\end{tabular}

Beberapa hal yang perlu diperhatikan pada LCD yaitu RS (register select), E (enable), $\mathrm{R} / \mathrm{W}$ (read/write). RS berfungsi untuk memilih antara dua register, yaitu intruction register (IR) atau data register (DR), di mana IR berguna mengirimkan data yang berupa perintah terhadap LCD seperti menghapus panel, penempatan kursor, menggeser kursor dll. Sedangkan DR berguna untuk mengirimkan data ASCII yang akan ditampilkan di panel. E (enable) berfungsi sebagai pengoperasian sinyal mulai, dan sinyal ini akan mengaktifkan pembacaan atau penulisan data pada LCD. Lalu R/W berfungsi sebagai pengaktif operasi pembacaan atau penulisan, di mana jika R/W di-set maka yang terjadi adalah operasi pembacaan sedangkan jika di-reset maka yang terjadi adalah operasi penulisan.

Dalam sistem, LCD digunakan sebagai penampil jumlah mobil yang dapat parkir. LCD ini ditempatkan pada pintu lantai 1 sehingga dapat diketahui lantai mana yang dapat memuat mobil untuk parkir. Apabila tidak terdapat ruang untuk parkir, maka LCD akan menampilkan "PENUH".

\section{METODE PENELITIAN}

A. Tahap-Tahap Dalam Perancangan Tugas Akhir

1) Desain area parkir

Desain area parkir dilakukan dengan tujuan untuk memudahkan perancangan alat yang akan dibuat.'

2) Perancangan blok diagram sistem

Perancangan blok diagram ini dilakukan dengan tujuan untuk mempermudah realisasi sistem yang akan dibuat.

3) Implementasi rangkaian, dengan tahaptahap sebagai berikut:

a. Menyusun rangkaian dari masingmasing blok diagram.

b. Menentukan komponen yang digunakan dalam tiap rangkaian.

c. Merangkai dan melakukan uji coba rangkaian dari masing-masing blok diagram.

d. Menggabungkan rangkaian dari setiap blok dalam papan percobaan (project board) dan dilakukan uji coba.

e. Membuat program dan kemudian memasukkannya ke dalam mikrokontroler (download).

f. Merangkai komponen dalam PCB.

4) Pengujian alat

Pengujian alat dilakukan untuk mengetahui tingkat keberhasilan alat yang dibuat.

5) Analisis dan simpulan, serta pembuatan laporan. 


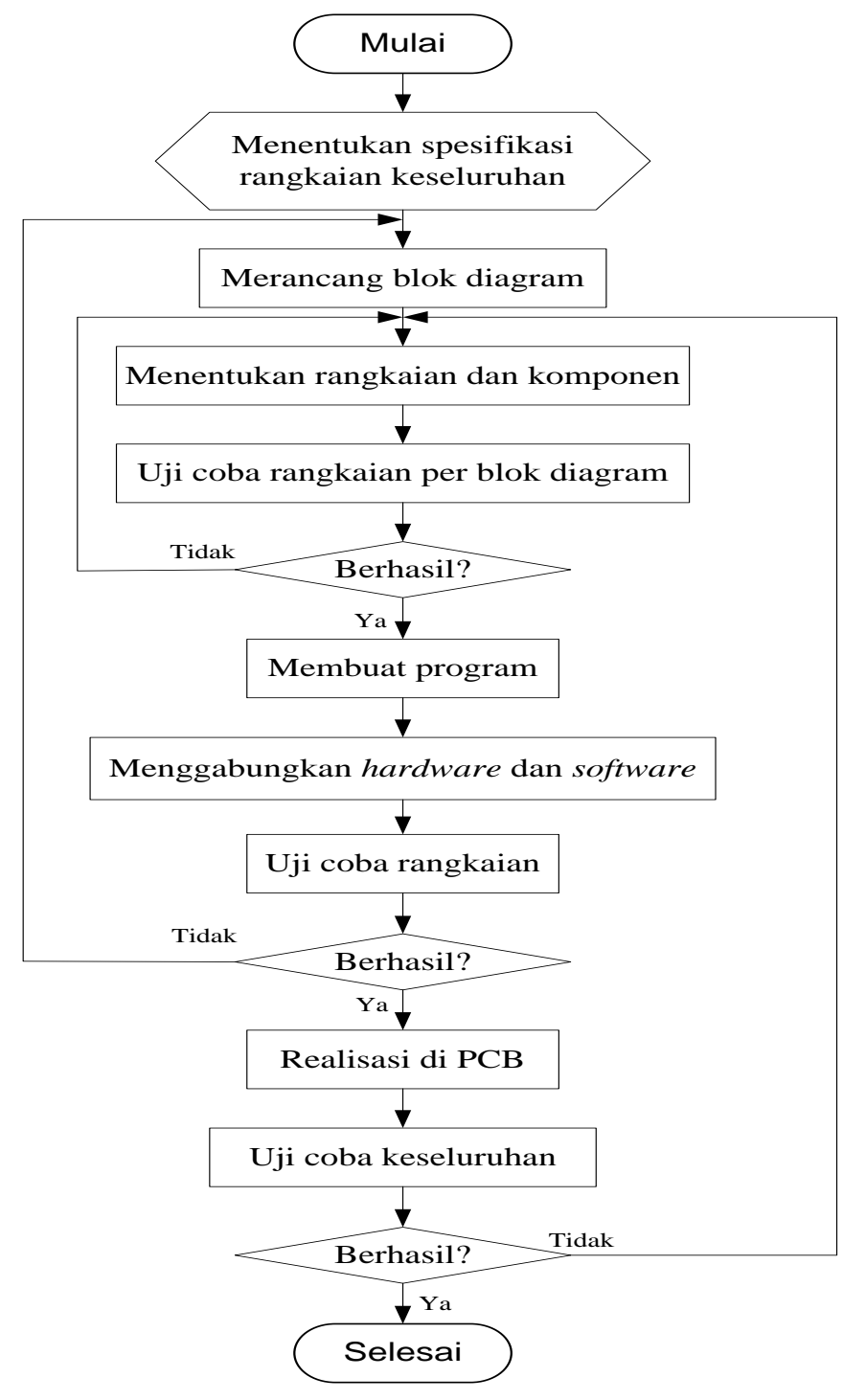

Gbr. 2 Diagram alir perancangan dan realisasi alat.

\section{B. Prosedur Kerja}

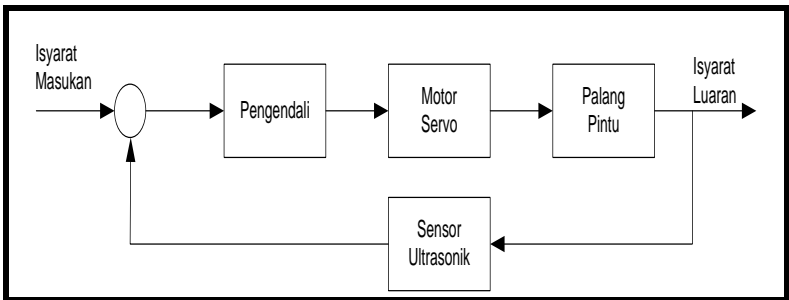

Gbr. 3 Blok diagram sistem hitung kendaraan area parkir bertingkat 2 .

Dari blok diagram sistem kendali dapat dijelaskan bahwa isyarat masukan yang diberikan akan dikendalikan oleh pengendali, dalam hal ini yaitu mikrokontroler ATMega8535. Selanjutnya pengendali akan mengatur motor servo untuk membuka dan menutup palang pintu pada area parkir. Keluaran dari sistem ini adalah pemenuhan jumlah kendaraan, dimana motor servo akan berputar sehingga palang pintu akan menutup saat jumlah kendaraan memenuhi kuota. Pada blok diagram sistem kendali ini terdapat feed back (umpan balik), yaitu sensor ultrasonik. Hal ini bertujuan untuk mendapatkan jumlah kendaraan yang terparkir pada lantai 1 dan lantai 2 yang sesuai dengan yang diinginkan. Dalam tahapan ini dilakukan perancangan menyeluruh terhadap rangkaian dan alat eksperimennya. Hasil dari perancangan sistem rangkaian adalah gambar rangkaian skematik secara menyeluruh. Berikut ini adalah rancangan alat penelitian menggunakan Mikrokontroler ATMega8535.

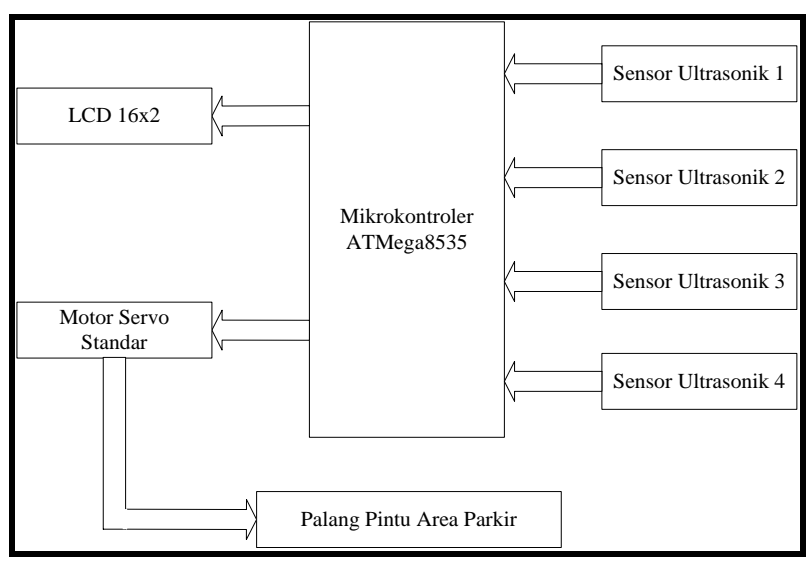

Gbr. 4 Blok diagram sistem penghitung kendaraan.

Dari gambar dijelaskan bahwa pada sistem penghitung kendaraan, mikrokontroler ATMega8535 merupakan pengendali pada sistem, dilengkapi dengan sensor ultrasonik sebagai masukan, LCD dan motor servo sebagai keluaran. Sensor ultrasonik memberikan data kepada mikrokontroler. Apabila terdapat benda melintas dengan jarak sisi samping lebih besar dari angka referensi untuk jarak benda, maka dapat dipastikan benda tersebut bukan kendaraan roda empat, melainkan manusia yang berjalan sehingga keluaran yang dihasilkan adalah 0 , dan counter tidak menambahkan atau mengurangi. Apabila terdapat benda melintas dengan jarak sisi samping sama dengan atau lebih kecil dari angka referensi untuk jarak benda, keluaran yang dihasilkan berupa 1, dan counter akan menambahkan atau mengurangi. Penambahan dan pengurangan yang dihasilkan oleh counter akan mempengaruhi tampilan pada LCD. LCD akan menampilkan angka kendaraan yang dapat parkir pada area tersebut apabila masih terdapat tempat parkir, dan akan menampilkan keterangan bahwa area parkir penuh pada saat counter menghitung jumlah kendaraan yang masuk area parkir sama dengan angka referensi jumlah kendaraan. Pada saat counter menghitung jumlah kendaraan yang masuk area parkir telah sama dengan angka referensi jumlah kendaraan, motor servo akan menggerakkan palang pintu untuk menutup pintu parkir.

Pengaturan dari alat hitung mobil ini terdiri atas : 
1. Penghitungan keluar masuknya mobil pada area parkir lantai 1 dan lantai 2.

2. Terbuka dan tertutupnya palang pintu pada area parkir lantai 1 dan lantai 2.

3. Tampilan jumlah mobil yang dapat diparkir baik di lantai 1 maupun di lantai 2 pada layar penampil dan dipasang di pintu masuk lantai 1.

Untuk penghitungan keluar masuknya mobil parkir, sistem akan menambahkan jumlah mobil yang sedang diparkir apabila mobil masuk ke area parkir dan akan mengurangi angka mobil yang sedang diparkir apabila mobil keluar dari area parkir. Hal ini berlaku pada tiap-tiap lantai, dan penghitungan jumlah mobil keseluruhan saling berkaitan. Untuk pengaturan terbuka dan tertutupnya palang pintu area parkir, palang pintu pada lantai 1 akan tetap pada posisi terbuka apabila jumlah mobil yang sedang parkir di bawah batas maksimal jumlah mobil yang dapat parkir di kedua lantai tersebut dan palang pintu akan tertutup apabila penghitung mobil parkir menunjukkan jumlah batas maksimal angka mobil parkir pada lantai 1 dan lantai 2 . Sedangkan pada lantai 2, palang pintu akan menutup bila angka mobil yang dapat parkir di lantai 2 mencapai batas maksimalnya. Untuk pengaturan tampilan jumlah mobil yang dapat diparkir, akan digunakan LCD sebagai penampil jumlah mobil yang dapat parkir di kedua lantai. Bila tidak ada tempat parkir yang kosong, LCD akan menampilkan LANTAI 1 PENUH atau LANTAI 2 PENUH.

Sistem penghitung mobil dilengkapi dengan sensor ultrasonik sebagai pendeteksi mobil yang akan melewati pintu parkir baik masuk maupun keluar. Sistem ini juga dilengkapi dengan motor servo standar sebagai penggerak palang pintu area parkir dengan gerakan sudut sebesar $90^{\circ}$. Kemudian dilengkapi dengan LCD 16x2 sebagai penampil jumlah mobil yang dapat diparkir maupun pemberitahuan bahwa parkir penuh di samping menutupnya palang pintu. Keseluruhan sistem ini dikendalikan dengan menggunakan mikrokontroler seri AVR ATMega8535.

\section{Perancangan Perangkat Keras}

Untuk membuat sistem hitung kendaraan pada area parkir bertingkat 2 secara otomatis terdapat empat bagian pokok, yaitu :

1) Rangkaian Pengendali

Rangkaian pengendali sistem hitung kendaraan pada area parkir bertingkat 2 dirancang dengan menggunakan software DipTrace serta pemrograman memori melalui
In-System Programming (ISP) Downloader. Mikrokontroler yang digunakan untuk rangkaian pengendali utamanya adalah mikrokontroler seri AVR, jenis ATMega8535. ATMega8535 memiliki 40 buah pin masukan/luaran. Jumlah pin masukan/luaran yang digunakan untuk digunakan untuk sensor ultrasonik sebanyak 4 pin masukan/luaran , 2 pin masukan/luaran digunakan untuk motor servo, 8 pin masukan/luaran digunakan untuk LED, 11 pin masukan/luaran digunakan untuk LCD.

Mikrokontroler ATMega8535 melakukan fungsi sebagai berikut:

1. Mengirimkan perintah kepada sensor ultrasonik untuk memindai objek.

2. Menerima data jarak dari sensor ultrasonik setelah memindai objek.

3. Mengirimkan data jarak kepada LED dalam bentuk biner.

4. Memberikan Pulse Width Modulation $(\mathrm{PWM})$ ke driver motor untuk menggerakkan motor servo pada kondisi tertentu.

5. Mengirimkan perintah kepada LCD untuk menampilkan data yang terdapat pada mikrokontroler.

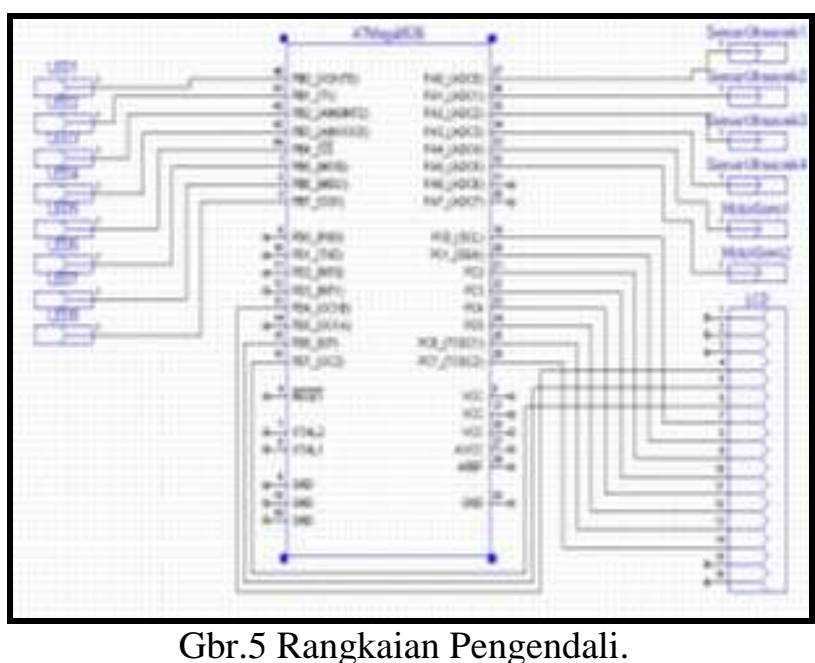

2) Sensor Pengukur Jarak Ultrasonik

Pada model sistem hitung kendaraan pada area parkir bertingkat 2 digunakan sensor ultrasonik sebagai pemindai objek/kendaraan dengan mengukur jarak sensor ultrasonik dengan atap kendaraan. Jarak yang dapat diukur oleh sensor ultrasonik memiliki rentang jarak antara $3-300 \mathrm{~cm}$. Karena sensor ultrasonik yang digunakan sudah berbentuk modul yang dapat langsung dihubungkan dengan pengendali utama, maka tidak dibutuhkan lagi rangkaian untuk pengkondisi sinyalnya.

Sensor ultrasonik ping parallax memiliki fitur sebagai berikut :

a. Supply Voltage - 5 VDC. 
b. Supply Current - $30 \mathrm{~mA}$ typ; $35 \mathrm{~mA}$ max

c. Range $-4 \mathrm{~cm}$ to $300 \mathrm{~cm}$.

d. Input Trigger - positive TTL pulse, $2 \mu \mathrm{s}$ min, $5 \mu$ s typ.

e. Echo Pulse-positive TTL pulse, $115 \mu$ s to $18.5 \mathrm{~ms}$.

f. Echo Hold-off- $750 \mu$ s from fall of Trigger pulse.

g. Frekuensi gelombang ultrasonik $-40 \mathrm{kHz}$ for $200 \mu \mathrm{s}$.

h. Indikator LED menyala apabila sensor aktif.

i. Delay before next measurement $-200 \mu \mathrm{s}$.

j. Size $-22 \mathrm{~mm} \mathrm{H}$ x $46 \mathrm{~mm} \mathrm{~W}$ x $16 \mathrm{~mm} \mathrm{D}$ (0.84 in $x 1.8$ in $x 0.6$ in).

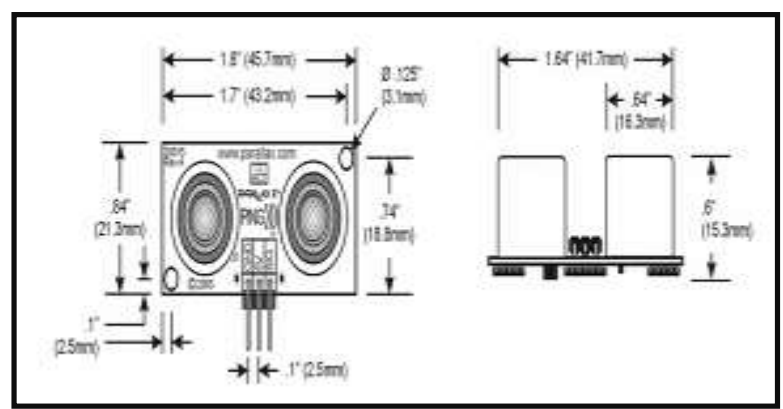

Gbr. 6 Sensor ultrasonik ping parallax.

3) Pembangkit Modulasi Lebar Pulsa (PWM)

Pada model sistem sistem hitung kendaraan pada area parkir bertingkat 2 digunakan motor servo sebagai penggerak palang pintu. Motor servo yang digunakan adalah motor servo standard Ping Parallax. Untuk menggerakan motor servo digunakan metoda PWM (Pulse Width Modulation). PWM adalah merupakan suatu metoda untuk mengatur kecepatan perputaran motor dengan cara mengatur prosentase lebar pulsa high terhadap perioda dari suatu sinyal persegi dalam bentuk tegangan periodik yang diberikan ke motor sebagai sumber daya. Semakin besar perbandingan waktu sinyal high dengan perioda sinyal, maka semakin cepat motor berputar.

Posisi perubahan jaraknya mencapai $180^{\circ}$. 3 buah warna kabel yang umumnya terdapat pada motor servo yaitu warna merah, hitam, dan putih (atau kuning). Kabel merah menunjukkan suplai tegangan $+5 \mathrm{~V}$, kabel hitam menunjukkan tegangan 0 volt, dan kabel putih(atau kuning) adalah posisi sinyal.Posisi sinyal adalah pemberian pulsa antara nilai 0.75 dan $2.25 \mathrm{~ms}$, diulang setiap kira-kira $18 \mathrm{~ms}$ (jadi ada pendekatan 50 pulsa per detik ). Dengan pulsa $1 \mathrm{~ms}$, motor servo akan berputar ke arah Counter Clock Wise (CCW). Dengan pulsa $1.5 \mathrm{~ms}$, servo akan berputar ke arah centre atau tengah. Dan dengan $2 \mathrm{~ms}$, servo akan berputar ke arah Clock Wise (CW). Gambar 7 menunjukkan pergerakan servo berdasarkan masukan pulsa.
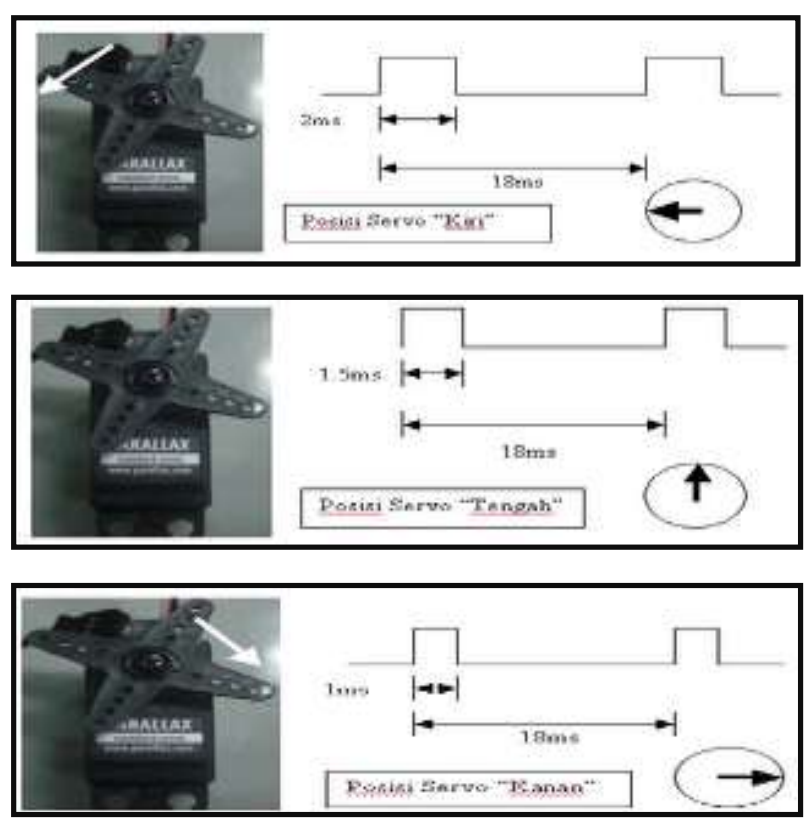

Gbr. 7 Gerak Motor Servo berdasarkan pulsa.

4) Liquid Crystal Display (LCD)

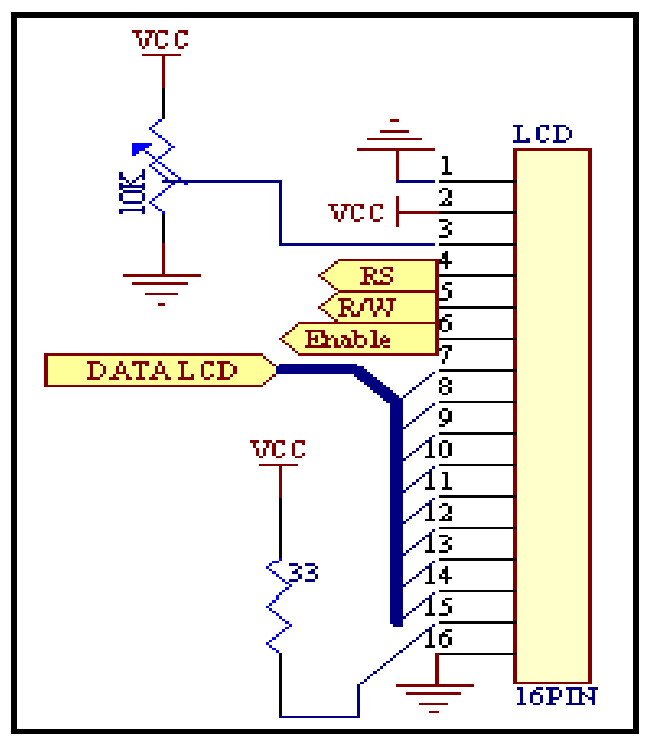

Gbr. 8 Rangkaian skematik LCD.

LCD digunakan sebagai penampil kuota parkir yang belum terisi. Pada saat area parkir dalam kondisi penuh, LCD akan menampilkan kata "PENUH" untuk menjelaskan kuota parkir yang tersisa.

\section{Perancangan Perangkat Lunak}


Perancangan dan pembuatan perangkat lunak membutuhkan pemahaman dan pengetahuan tentang bahasa Assembler. Perangkat lunak yang direncanakan untuk mikrokontroler ATMega8535 mempunyai fungsi sebagai berikut :

1. Mengirimkan perintah kepada sensor ultrasonik untuk memindai objek.

2. Menerima data jarak dari sensor ultrasonik setelah memindai objek.

3. Mengirimkan data jarak kepada LED dalam bentuk biner.

4. Memberikan Pulse Width Modulation (PWM) ke driver motor untuk menggerakkan motor servo pada kondisi tertentu.

5. Mengirimkan perintah kepada LCD untuk menampilkan data yang terdapat pada mikrokontroler.

Mikrokontroler memberikan perintah mengaktifkan sensor ultrasonik untuk mengambil data jarak objek yang dipindai. Sensor ultrasonik yang telah mendapatkan data jarak akan mengirimkannya ke mikrokontroler. Selanjutnya mikrokontroler akan memroses apakah data jarak tersebut memenuhi kualifikasi untuk dinyatakan sebagai jarak sensor ultrasonik terhadap kendaraan. Apabila data jarak tersebut memenuhi kualifikasi, maka mikrokontroler akan menambahkan data jumlah kendaraan pada register yang telah ditentukan.

Kemudian pada kondisi data tertentu untuk jumlah kendaraan pada register, mikrokontroler mengendalikan motor servo untuk membuka atau menutup palang pintu. Mikrokontroler juga akan mengirimkan data ke LCD berupa data jumlah lahan parkir yang belum terisi.

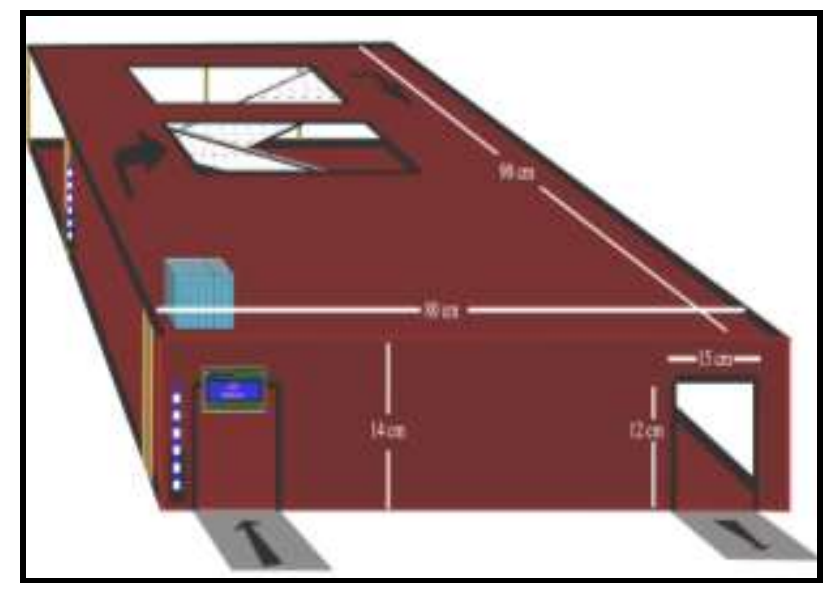

Gbr. 9 Desain model area parkir.

IV. HASIL DAN PEMBAHASAN

\section{A. Perangkat Keras}

Sebelum merangkai suatu piranti, sebaiknya dilakukan pengujian terlebih dahulu pada masing-masing perangkat keras yang digunakan dengan tujuan untuk mengetahui apakah perangkat keras yang akan digunakan berfungsi dengan baik. Hal ini sangat membantu dalam troubleshooting sehingga kemungkinan kesalahan pada piranti semakin kecil. Adapun perangkat keras yang diuji antara lain:

1. Pengendali utama

2. Sensor ultrasonik

3. Motor servo

4. Liquid Crystal Display (LCD)

5. Power supply.

\section{B. Pengujian Pengendali Utama}

Pengendali utama adalah subsistem yang terdiri atas mikrokontroler di mana kaki-kaki mikrokontroler terhubung dengan pin konektor untuk sensor ultrasonik, motor servo, dan LCD. Pengujian terhadap pengendali utama bertujuan untuk mengetahui apakah mikrokontroler dapat bekerja dalam kondisi baik atau tidak dan apakah kaki-kaki mikrokontroler terhubung dengan pin konektor atau tidak. Pengujian pada mikrokontroler dilakukan dengan memeriksa kaki-kaki mikrokontroler. Apabila mikrokontroler diberi logika high, tegangan yang terukur sekitar 4,5 - 5,5 V. Dan apabila diberikan logika low, tegangan yang terukur mendekati $0 \mathrm{~V}$. Nilai tersebut tertera pada datasheet mikrokontroler ATMega8535 sebagai pembanding untuk pemeriksaan. Pengujian pada mikrokontroler ATMega8535 dilakukan dengan mengambil sampel yaitu mengukur tegangan pada PA3, PB5, PC4, dan PD1.

Tabel 2 Hasil pengujian tegangan pada mikrokontroler ATMega8535

\begin{tabular}{|c|c|c|c|c|}
\hline Logika & $\begin{array}{c}\mathrm{V} \mathrm{di} \\
\text { PA3 }\end{array}$ & $\begin{array}{c}\mathrm{V} \text { di } \\
\text { PB5 }\end{array}$ & $\begin{array}{c}\text { V di } \\
\text { PC4 }\end{array}$ & $\begin{array}{c}\text { V di } \\
\text { PD1 }\end{array}$ \\
\hline High & $4,46 \mathrm{~V}$ & $4,67 \mathrm{~V}$ & $4,52 \mathrm{~V}$ & $4,58 \mathrm{~V}$ \\
\hline Low & 0,07 & 0,08 & 0,07 & 0,07 \\
& $\mathrm{mV}$ & $\mathrm{mV}$ & $\mathrm{mV}$ & $\mathrm{mV}$ \\
\hline
\end{tabular}

Data yang didapat dari pemberian logika high dan logika low pada mikrokontroler yang diukur dengan menggunakan multimeter digital menunjukkan bahwa tegangan mikrokontroler berkisar antara 4,4 Volt sampai 4,7 Volt untuk pemberian logika high dan 0,07 Volt untuk pemberian logika low. Nilai yang didapat sesuai dengan datasheet ATMega8535. Dari pengujian ini, dapat dinyatakan 
mikrokontroler dalam kondisi baik dan dapat digunakan untuk mengeksekusi program pada piranti. Kemudian mikrokontroler diletakkan pada zip socket yang terhubung dengan pin konektor, dan dilakukan pemeriksaan dengan menggunakan multimeter. Hal ini bertujuan untuk mengetahui apakah antara kaki-kaki mikrokontroler dengan pin konektor benarbenar terhubung atau ada yang tidak terhubung.

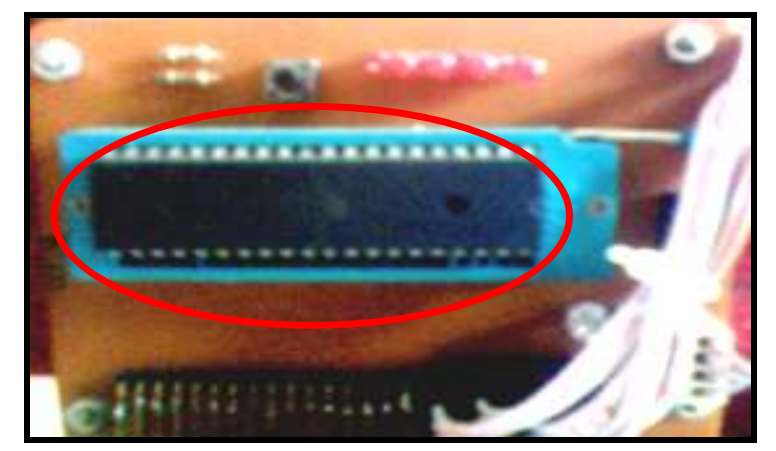

Gbr. 10 Pengendali Utama.

Tabel 3 Hasil pengujian hubungan kaki-kaki mikrokontroler ATMega8535 dengan pin konektor

\begin{tabular}{|l|l|c|l|}
\hline \multirow{2}{*}{$\begin{array}{c}\text { Kaki } \\
\text { Mikrokontroler }\end{array}$} & \multirow{2}{*}{$\begin{array}{c}\text { Pin Konektor } \\
\text { Untuk }\end{array}$} & \multicolumn{2}{|c|}{ Terhubung } \\
\cline { 3 - 5 } & & Ya & Tidak \\
\hline PA0 & Motor servo 1 & $\checkmark$ & \\
\hline PA1 & $\begin{array}{l}\text { Sensor } \\
\text { ultrasonik 1 }\end{array}$ & $\checkmark$ & \\
\hline PA2 & Motor servo 2 & $\checkmark$ & \\
\hline PA3 & $\begin{array}{l}\text { Sensor } \\
\text { ultrasonik 2 }\end{array}$ & $\checkmark$ & \\
\hline PA5 & $\begin{array}{l}\text { Sensor } \\
\text { ultrasonik 3 }\end{array}$ & $\checkmark$ & \\
\hline PA7 & $\begin{array}{l}\text { Sensor } \\
\text { ultrasonik 4 }\end{array}$ & $\checkmark$ & \\
\hline PC0 & DB0 pada LCD & $\checkmark$ & \\
\hline PC1 & DB1 pada LCD & $\checkmark$ & \\
\hline PC2 & DB2 pada LCD & $\checkmark$ & \\
\hline PC3 & DB3 pada LCD & $\checkmark$ & \\
\hline PC4 & DB4 pada LCD & $\checkmark$ & \\
\hline PC5 & DB5 pada LCD & $\checkmark$ & \\
\hline PC6 & DB6 pada LCD & $\checkmark$ & \\
\hline PC7 & DB7 pada LCD & $\checkmark$ & \\
\hline PD4 & RS pada LCD & $\checkmark$ & \\
\hline PD6 & R/W pada LCD & $\checkmark$ & \\
\hline PD7 & E pada LCD & $\checkmark$ & \\
\hline
\end{tabular}

\section{Pengujian Sensor Ultrasonik}

Pengujian sensor ultrasonik dilakukan dengan meletakkan sensor ultrasonik di lantai dengan posisi transmitter dan receiver sensor menghadap langit-langit. Kemudian sebuah penggaris diposisikan dalam keadaan vertikal untuk membandingkan jarak benda yang terukur dengan nilai-nilai digital yang ditampilkan pada 8 buah LED.

Terdapat 3 pin pada sensor ultrasonik yaitu SIG, 5 Volt, dan GND. Untuk dapat digunakan sebagai pengukur jarak, pin SIG pada sensor ultrasonik dihubungkan pada salah satu pin I/O pada mikrokontroler, dan pin 5 Volt dan GND dihubungkan dengan power supply. Kemudian 8 buah LED dihubungkan pada masing-masing pin I/O mokrokontroler. Untuk melakukan suatu perhitungan, dibutuhkan sebuah variabel jarak yang digunakan untuk menghitung jarak yang terukur dengan nilai 0 sebagai perhitungan mula jarak sensor pada langitlangit. Karena jumlah LED yang digunakan dalam pemeriksaan sensor ultrasonik terdapat 8 buah, maka pengaturan jarak yang dapat diukur dibatasi dengan besar maksimal 128 $\mathrm{cm}$, dengan meletakkan penggaris secara vertikal sebagai pengambilan titik jarak dari sensor ultrasonik terhadap benda. Setelah itu, dilakukan beberapa kali percobaan dengan memposisikan benda sejauh kira-kira $3 \mathrm{~cm}, 4$ $\mathrm{cm}, 5 \mathrm{~cm}, 6 \mathrm{~cm}, 7 \mathrm{~cm}, 8 \mathrm{~cm}, 16 \mathrm{~cm}, 32 \mathrm{~cm}, 64$ $\mathrm{cm}$, dan $128 \mathrm{~cm}$.

Tabel 4 Hasil pengukuran jarak sensor ultrasonik terhadap benda dengan penggaris sebagai acuan.

\begin{tabular}{|c|c|}
\hline $\begin{array}{c}\text { Jarak Benda terhadap Sensor } \\
\text { Ultrasonik dengan Penggaris } \\
\text { sebagai Acuan }\end{array}$ & $\begin{array}{c}\text { LED yang } \\
\text { Menyala } \\
\text { (High) }\end{array}$ \\
\hline $3,2 \mathrm{~cm}$ & 00000011 \\
\hline $4,1 \mathrm{~cm}$ & 00000100 \\
\hline $5 \mathrm{~cm}$ & 00000101 \\
\hline $6 \mathrm{~cm}$ & 00000110 \\
\hline $7 \mathrm{~cm}$ & 00000111 \\
\hline $8 \mathrm{~cm}$ & 00001000 \\
\hline $16 \mathrm{~cm}$ & 00010000 \\
\hline $32 \mathrm{~cm}$ & 00100000 \\
\hline $64 \mathrm{~cm}$ & 01000000 \\
\hline $128 \mathrm{~cm}$ & 10000000 \\
\hline
\end{tabular}

Percobaan ini dilakukan pada empat sensor ultrasonik yang berbeda, yang kemudian akan digunakan pada rangkaian dan terpasang pada setiap pintu sebagai pemindai adanya kendaraan yang lewat nantinya.

\section{Pengujian Motor Servo}

Pengujian motor servo ditujukan agar motor servo dapat memutar sesuai dengan posisi yang diinginkan dan layak untuk digunakan. Pengujian pada motor servo dilakukan dengan melihat pulsa yang diberikan mikrokontroler pada osiloskop. Pulsa yang 
diberikan harus dapat memutar motor servo ke posisi $0^{0}$ dan ke posisi $90^{\circ}$. Pada gambar 19 berikut adalah pulsa yang dikirimkan ke motor servo untuk memutar motor servo ke posisi $90^{0}$.

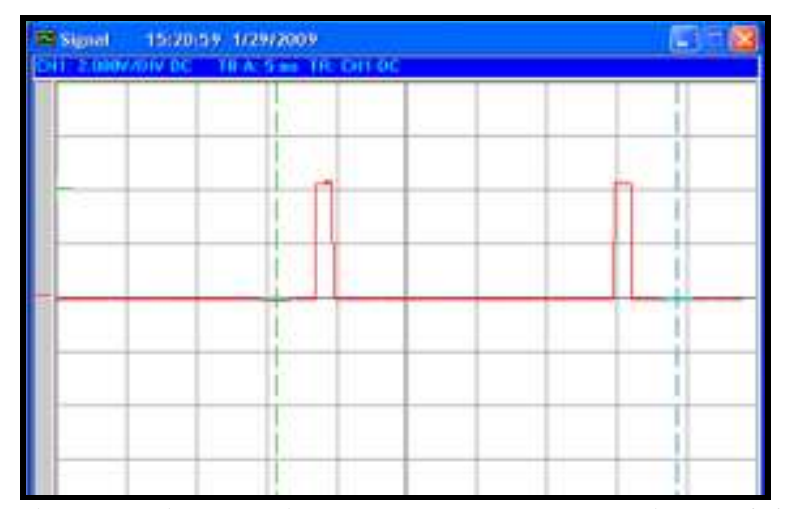

Gbr.10 Pulsa untuk memutar motor servo ke posisi $90^{\circ}$

Panjang pulsa yang diberikan sebesar 1,25 ms untuk nilai high, dan pengulangan terjadi setiap $20 \mathrm{~ms}$. Dengan demikian, motor servo akan berputar ke posisi $90^{\circ}$. Pemberian panjang pulsa untuk memutar motor servo ke posisi $90^{\circ}$ pada hasil pengujian sedikit berbeda dengan dasar teori. Pada dasar teori pemberian panjang pulsa untuk memutar motor servo ke posisi $90^{\circ}$ sebesar $1,5 \mathrm{~ms}$. Sedikit berbeda dengan data hasil pengujian yang didapat. Walaupun demikian motor servo masih tetap layak untuk digunakan pada perancangan alat untuk tugas akhir ini.

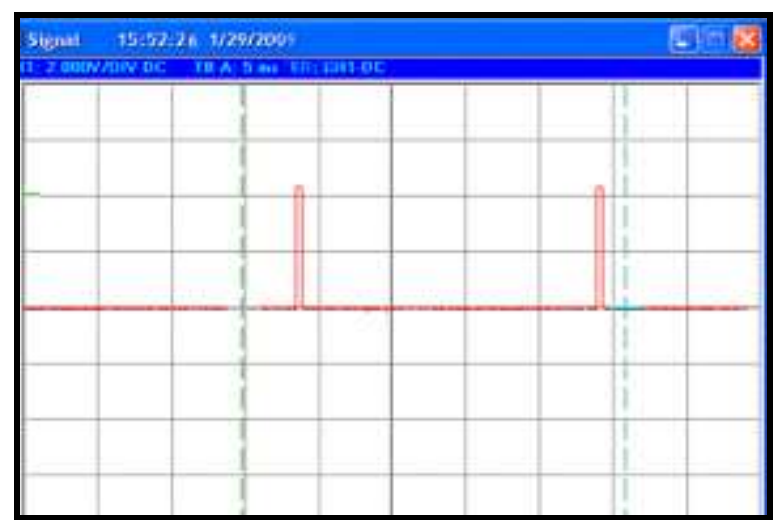

Gbr.11 Pulsa yang diberikan untuk memutar motor servo ke posisi $0^{0}$.

Panjang pulsa yang diberikan untuk nilai high sebesar 0,4 ms. Dan akan diulang setiap $20 \mathrm{~ms}$. Motor servo tersebut akan berputar ke posisi $0^{0}$. Pemberian panjang pulsa untuk memutar motor servo ke posisi $0^{0}$ sedikit berbeda dengan dasar teori yang didapat. Pada dasar teori pemberian panjang pulsa untuk memutar motor servo ke posisi $0^{0}$ sebesar $1,25 \mathrm{~ms}$. Sehingga dapat disimpulkan bahwa motor servo yang digunakan untuk memutar motor servo ke posisi $0^{\circ}$ dan $90^{\circ}$ sudah tidak sesuai dengan dasar teori yang didapat, namum motor servo tetap dapat digunakan.

\section{E. Pengujian Liquid Crystal Display (LCD) \\ Pengujian Liquid Crystal Display (LCD)} bertujuan untuk mengetahui apakah LCD dapat bekerja dengan baik dan dapat menampilkan karakter yang diinginkan. Pengujian pada LCD dilakukan dengan cara menghubungkan masing-masing pin pada LCD yang sesuai dengan fungsinya. Berikut adalah tabel fungsi pin pada LCD.

Setelah kaki-kaki LCD terhubung, pengendali utama diprogram untuk menampilkan karakter. Apabila karakter yang ditampilkan pada LCD sesuai dengan karakter yang diprogram pada mikrokontroler, maka LCD bekerja dengan baik.

Tabel 5 Fungsi pin pada LCD yang terhubung dengan komponen lain

\begin{tabular}{|c|l|l|}
\hline Pin & \multicolumn{1}{|c|}{ Fungsi } & \multicolumn{1}{c|}{ Komponen Lain } \\
\hline 1 & Ground & Titik Ground pada powersupply \\
\hline 2 & Masukan tegangan & Titik 5 Volt pada power supply \\
\hline 3 & $\begin{array}{l}\text { Pengatur } \\
\text { kekontrasan }\end{array}$ & Power supply \\
\hline 4 & $\begin{array}{l}\text { Register Select } \\
\text { Signal }\end{array}$ & PD4 pada mikrokontroler \\
\hline 5 & Read/Write Signal & PD6 pada mikrokontroler \\
\hline 6 & Enable Signal & PD7 pada mikrokontroler \\
\hline 7 & Jalur bus data & PC0 pada mikrokontroler \\
\hline 8 & Jalur bus data & PC1 pada mikrokontroler \\
\hline 9 & Jalur bus data & PC2 pada mikrokontroler \\
\hline 10 & Jalur bus data & PC3 pada mikrokontroler \\
\hline 11 & Jalur bus data & PC4 pada mikrokontroler \\
\hline 12 & Jalur bus data & PC5 pada mikrokontroler \\
\hline 13 & Jalur bus data & PC6 pada mikrokontroler \\
\hline 14 & Jalur bus data & PC7 pada mikrokontroler \\
\hline 15 & $\begin{array}{l}\text { Tegangan keluaran } \\
\text { negatif }\end{array}$ & Titik 5 volt pada power supply \\
\hline 16 & Ground & $\begin{array}{l}\text { Titik ground pada power } \\
\text { supply }\end{array}$ \\
\hline
\end{tabular}

\section{F. Pengujian Power supply}

Pengujian power supply bertujuan untuk mengetahui apakah tegangan yang dihasilkan oleh power supply sesuai dengan yang diinginkan atau tidak. Pada power supply yang dibuat, tegangan keluaran yang diharapkan sebesar 5 Volt dan arus yang dihasilkan searah.

Gambar 12 merupakan gambar power supply yang digunakan pada rangkaian. Power supply yang digunakan merupakan power supply sederhana yang telah diuji stabilitas keluaran tegangannya sehingga aman digunakan pada rangkaian dan tidak membahayakan komponen yang digunakan. Pada power supply dipasangkan IC LM7805 sehingga tegangan keluaran stabil dan berkisar pada 5 Volt. 


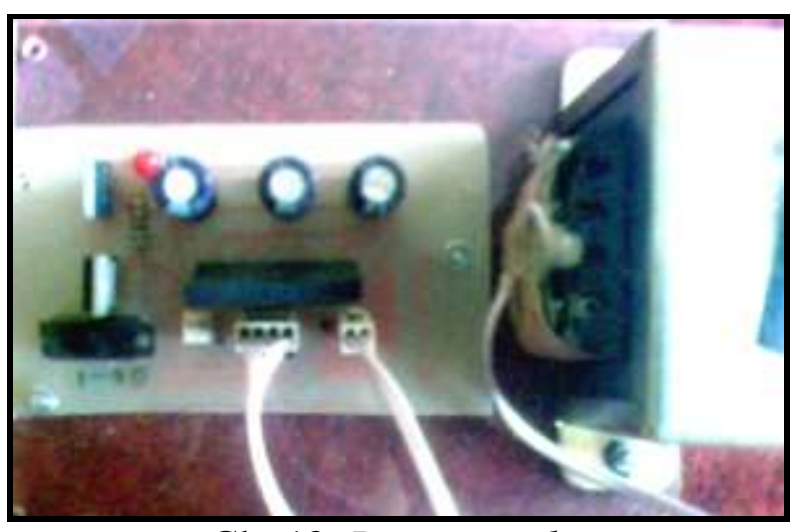

Gbr.12 Power supply.

Komponen-komponen yang digunakan untuk membuat power supply antara lain :
1. Dioda Bridge
2. Kapasitor
3. Resistor
4. IC LM7805
5. LED
6. Transformator Step Down
7. Pin konektor

Pada gambar 13 dapat dilihat gambar skematik power supply yang digunakan untuk penelitian tugas akhir. Arus yang mengalir dari transformator step down merupakan arus bolak-balik yang selanjutnya masuk ke dioda bridge. Pada dioda bridge, arus sedemikian rupa diproses sehingga keluaran dari dioda bridge merupakan arus searah yang memiliki riak-riak cukup besar. Riak-riak besar yang merupakan keluaran dari dioda bridge diperhalus dengan menggunakan tiga buah kapasitor. Kapasitor tersebut disusun secara paralel. Semakin banyak kapasitor yang digunakan maka akan semakin halus riak-riak yang dikeluarkan dari kapasitor tersebut. Keluaran dari kapasitor terhubung dengan IC LM7805, yang akan menghasilkan keluaran tegangan sebesar 5 Volt. Tegangan inilah yang kemudian digunakan pada rangkaian. Untuk mengindikasikan power supply dapat bekerja dengan baik, ditambahkan LED sebagai indikator mengalirnya arus dan saklar untuk memutus-hubungkan arus listrik.

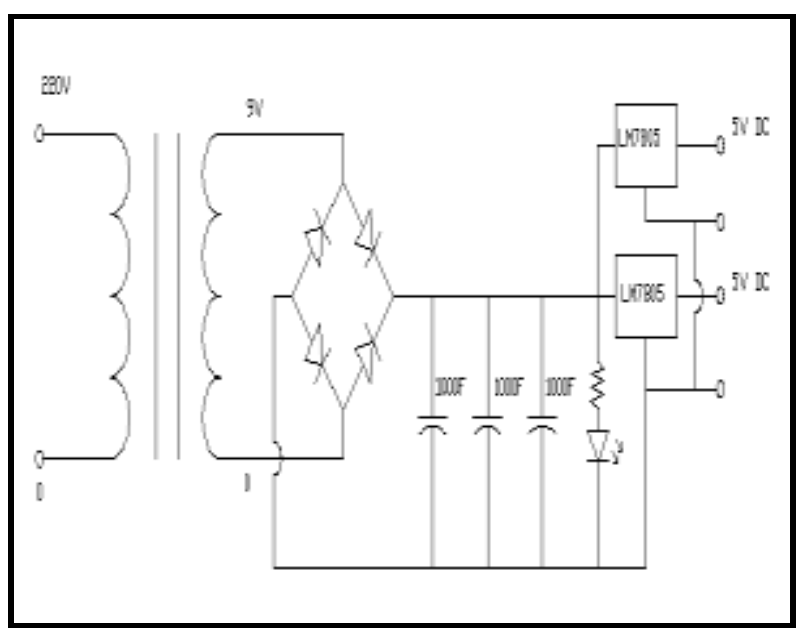

Gbr. 13 Gambar skematik power supply dengan keluaran 5 Volt.

Gambar 14 merupakan gambar rangkaian power supply yang digunakan pada piranti. Pada gambar, dapat dilihat masukan terhubung ke kaki ke 2 dan ke 3 dioda bridge. Pada dioda bridge, arus diproses sedemikian rupa, dan keluaran dari dioda bridge terhubung ke tiga buah kapasitor yang tersusun paralel. Keluaran dari kapasitor terhubung pada konektor keluaran 9 volt, dan diteruskan ke IC LM7805. Keluaran IC LM 7805 inilah yang kemudian menjadi keluaran 5 volt arus searah dari rangkaian power supply di bawah ini.

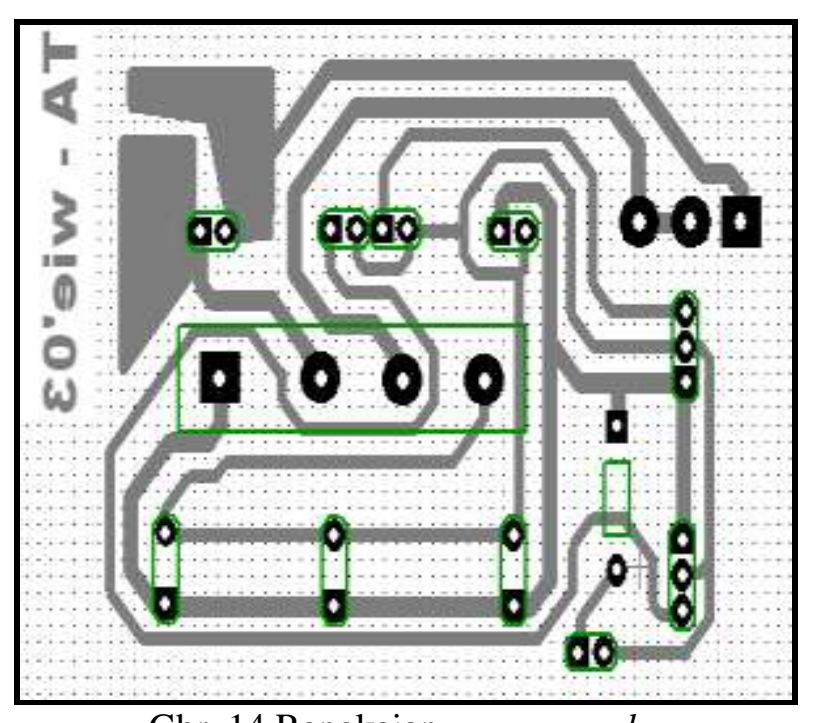

Gbr. 14 Rangkaian power supply. 


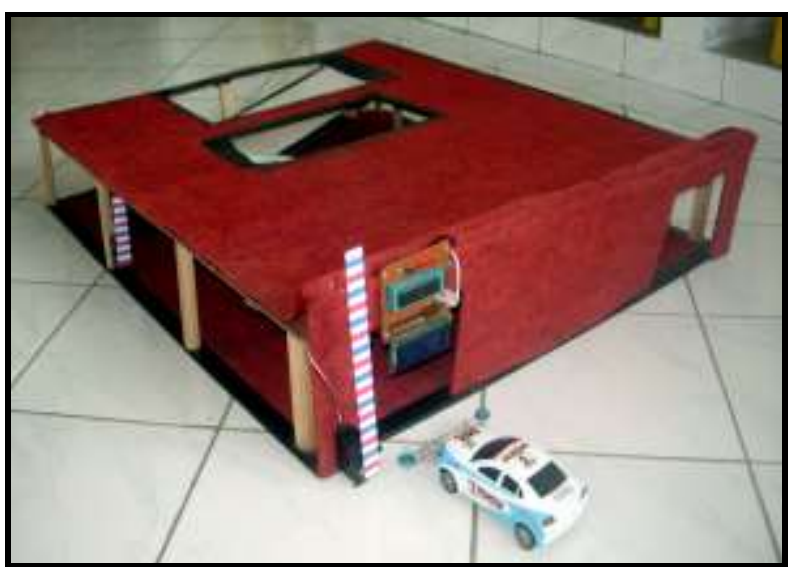

Gbr. 15 Model sistem hitung kendaraan parkir 2 lantai.

Motor servo terpasang di sisi kiri pintu masuk, baik di pintu masuk utama menuju lantai 1 maupun di pintu masuk dari lantai 1 menuju lantai 2. Sensor ultrasonik dipasang pada langit-langit di lantai 1 . Sensor ultrasonik 1 terpasang di langit-langit pintu masuk utama, sensor ultrasonik 2 tepasang di langit-langit pintu masuk dari lantai 1 menuju lantai 2 , sensor ultrasonik 3 terpasang di langit-langit saat keluar dari lantai 2 menuju lantai 1, dan sensor ultrasonik 4 terpasang di langit-langit pintu keluar dari lantai 1.

Dalam penelitian tugas akhir ini, dirancang sebuah piranti yang dapat menghitung secara otomatis masuk dan keluarnya jumlah kendaraan pada area parkir dan mengontrol jumlah kendaraan yang memadati area parkir. Pengujian pada piranti dilakukan dengan tujuan untuk mengetahui apakah alat yang digunakan dapat bekerja secara maksimal atau tidak. Piranti yang dibuat merupakan piranti otomatis, sehingga dapat bekerja secara otomatis tanpa pengawasan, dengan catatan tidak terjadi pemutusan aliran listrik ke piranti. Piranti ini bekerja satu siklus, terus-menerus. Apabila aliran listrik ke piranti putus, maka piranti tidak akan menyimpan data sebelumnya. Tahap awal pembuatan piranti adalah dengan memrogram mikrokontroler ATMega8535 sebagai pengendali utama. Program-program awal untuk menguji komponen seperti sensor ultrasonik, motor servo, dan LCD dimodifikasi dan digabungkan sehingga membentuk sebuah perangkat lunak. Perangkat lunak yang telah dibuat terprogram ke mikrokontroler. Kemudian komponenkomponen piranti yang berupa power supply, sensor ultrasonik, motor servo, dan LCD terhubung ke mikrokontroler.

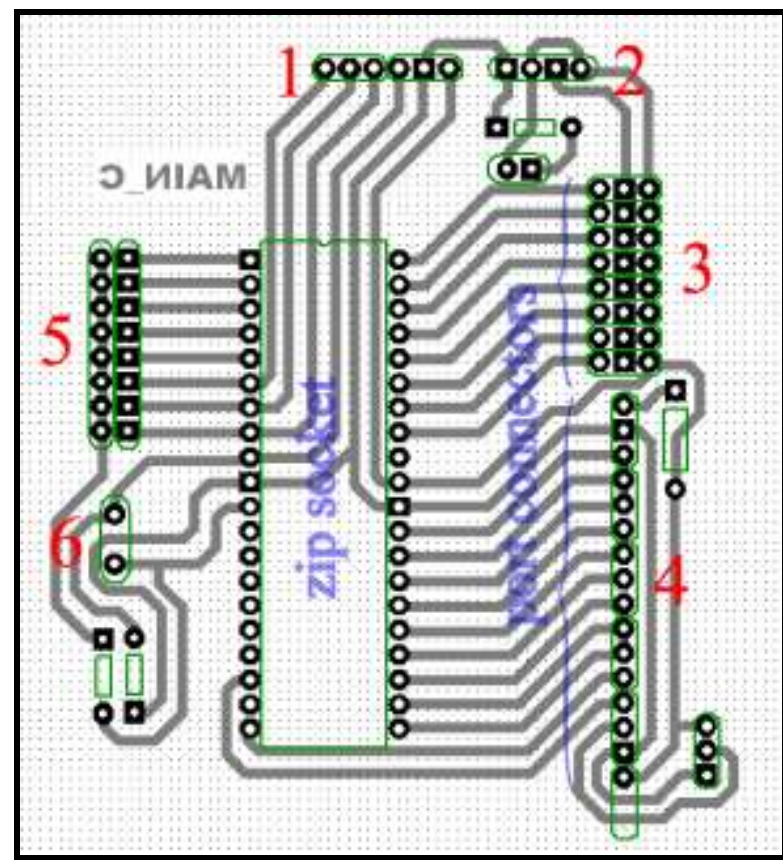

Gbr.16 Rangkaian piranti.

Gambar 16 merupakan gambar rangkaian piranti di mana zip socket sebagai tempat peletakan mikrokontroler dengan jelas terhubung dengan komponen-komponen lain yang digunakan. Pada gambar terdapat angkaangak dari 1 sampai 6 yang merupakan pin konektor yang terhubung dengan bagianbagian dari piranti.

Angka 1 pada gambar 16 merupakan pin konektor downloader, di mana untuk memprogram mikrokontroler digunakan downloader sebagai penghubung antara komputer dengan mikrokontroler. Terdapat 6 pin pada konektor downloader. Tersusun dari kanan ke kiri 6 pin tersebut adalah ground, tegangan 5 Volt arus searah, kaki ke 9 mikrokontroler yang merupakan reset, kaki ke 8 mikrokontroler yang merupakan SCK, kaki ke 7 mikrokontroler yang merupakan MISO, kaki ke 6 mikrokontroler yang merupakan MOSI. Angka 2 pada gambar 16 merupakan konektor untuk power supply. Pada power supply terdapat 2 keluaran tegangan sebesar 5 volt arus searah, hal ini dikarenakan pada power supply digunakan 2 buah IC LM7805 untuk meminimalisasi rusaknya IC LM7805 akibat arus yang melewati IC tersebut terlalu besar. Keluaran power supply yang pertama terhubung pada komponen-komponen yang terdiri dari 4 buah sensor ultrasonik, 2 buah motor servo, dan 1 buah LCD konsumsi daya rendah. Keluaran power supply yang kedua terhubung dengan mikrokontroler. Suplai tegangan mikrokontroler dikhususkan jalurnya tersendiri/tidak terhubung dengan komponen lain agar kinerja mikrokontroler tidak terganggu akibat kurangnya tegangan masukan. Angka 3 pada gambar 16 terdapat 8 buah konektor dengan 3 pin pada masing- 
masing konektornya. Bagian paling kiri merupakan pin konektor yang terhubung dengan port A dari pin A0 sampai pin A7. Pin konektor ini digunakan untuk sensor ultrasonik dan motor servo. Dari 8 pin konektor yang tersedia, hanya digunakan 6 buah pin konektor saja dikarenakan hanya terdapat 4 buah sensor ultrasonik dan 2 buah motor servo.Pin konektor bagian tengah terhubung dengan pin konektor untuk power supply tegangan 5 volt arus searah yang tersusun secara paralel. Bagian paling kanan adalah pin konektor yang tehubung dengan ground. Angka 4 pada gambar 16 merupakan pin konektor yang terhubung dengan LCD. Konfigurasi pin LCD dari bawah ke atas dapat dijelaskan oleh Tabel 3 . Angka 5 pada gambar 16 merupakan pin konektor yang terhubung dengan LED. Fungsi dari LED ini adalah sebagai indikator terukurnya jarak objek dengan sensor ultrasonik. Sistem yang digunakan untuk jarak ukur ini adalah dengan menggunakan bilangan biner. Pin paling atas merupakan LSB dan pin paling bawah merupakan MSB. Angka 6 pada gambar 16 merupakan pin konektor yang terhubung dengan kaki mikrokontroler sebagai reset.

Gambar 17 merupakan diagram alir kinerja sensor ultrasonik pada piranti. Saat mula piranti dihidupkan, yang pertama kali bekerja adalah sensor ultrasonik 1 , kemudian sensor ultrasonik2, sensor ultrasonik 3, dan sensor ultrasonik 4 secara berurutan. Proses ini terus berkesinambungan sampai aliran listrik pada piranti diputuskan. Sensor ultrasonik 1 berada pada pintu masuk utama menuju lantai 1. Apabila terdapat objek, dalam hal ini kendaraan roda 4 tanpa celah yang dipindai oleh sensor ultrasonik 1, maka pada R16 mikrokontroler ditambahkan 1 dari jumlah kendaraan yang mengisi lantai 1 , kemudian kembali sensor ultrasonik 1 bekerja. Apabila tidak terdapat objek yang dipindai oleh sensor ultrasonik 1, maka sensor ultrasonik 2 bekerja. Sensor ultrasonik 2 berada di lantai 1 menuju pintu masuk lantai 2. Saat sensor ultrasonik 2 memindai objek, maka pada R16 mikrokontroler dikurangkan 1 dari jumlah kendaraan yang mengisi lantai 1 dan pada R17 mikrokontroler ditambahkan 1 dari jumlah kendaraan yang mengisi lantai 2, kemudian sensor ultrasonik 1 kembali bekerja. Apabila tidak terdapat objek yang dipindai oleh sensor ultrasonik 2, maka sensor ultrasonik 3 bekerja.

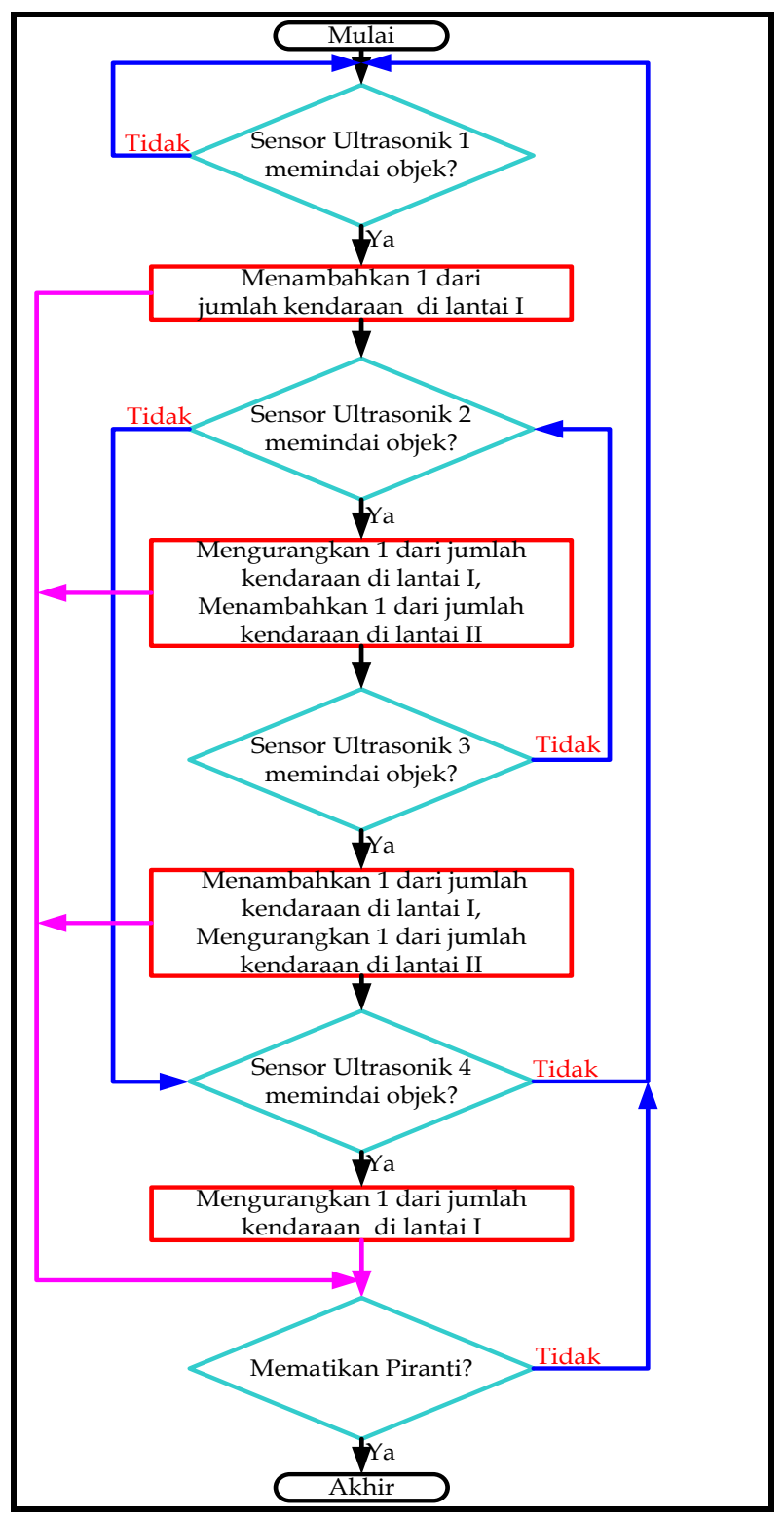

Gambar 17 Diagram alir kinerja sensor ultrasonik pada piranti.

Sensor ultrasonik 3 terpasang di lantai 1 keluar dari lantai 2 menuju lantai 1. Saat sensor ultrasonik 3 memindai objek, maka pada R17 mikrokontroler dikurangkan 1 dari jumlah kendaraan yang mengisi lantai 2 dan pada R16 mikrokontroler ditambahkan 1 dari jumlah kendaraan yang mengisi lantai 1, kemudian sensor ultrasonik 1 kembali bekerja. Apabila tidak terdapat objek yang dipindai oleh sensor ultrasonik 3, maka sensor ultrasonik 4 bekerja. Sensor ultrasonik 4 terpasang di pintu keluar utama dari lantai 1. Saat sensor ultrasonik 4 memindai objek, maka pada R16 mikrokontroler dikurangkan 1 dari jumlah kendaraan yang mengisi lantai 1, kemudian sensor ultrasonik 1 kembali bekerja. Apabila tidak terdapat objek yang dipindai oleh sensor ultrasonik 4, maka sensor ultrasonik 1 bekerja. 


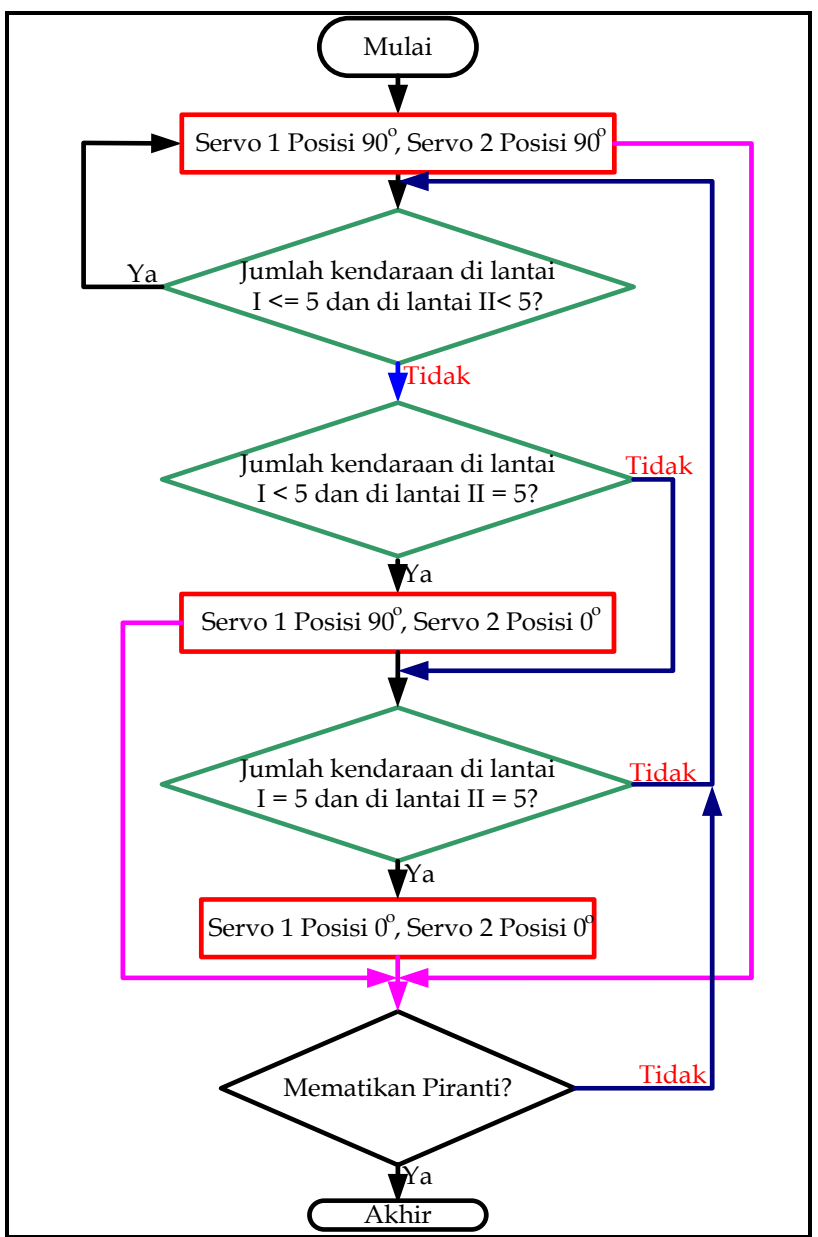

Gbr. 18 Diagram alir kinerja motor servo pada piranti.

Gambar 18 merupakan diagram alir kinerja motor servo pada piranti. Saat piranti dihidupkan, motor servo 1 dan motor servo 2 berada pada posisi $90^{\circ}$ di mana palang pintu dalam keadaan terbuka. Apabila jumlah kendaraan yang mengisi lantai 1 berjumlah 5 buah dan kendaraan yang mengisi lantai 2 berjumlah 5 buah, maka motor servo 1 dan motor servo 2 memutar ke posisi $0^{0}$. Kondisi palang pintu pada pintu masuk utama dan pintu masuk dari lantai 1 menuju lantai 2 dalam keadaan tertutup. Hal ini tidak berlaku untuk kondisi jumlah kendaraan yang mengisi lantai 1 berjumlah kurang dari 5 buah dan kendaraan yang mengisi lantai 2 berjumlah 5 buah. Yang akan bekerja hanya motor servo 2 , memutar ke posisi $0^{0}$ dan palang pintu masuk dari lantai 1 menuju lantai 2 dalam keadaan tertutup.

Apabila jumlah kendaraan yang mengisi lantai 1 dan lantai 2 kurang dari 5 buah, maka posisi motor servo yang terpasang pada pintu masuk utama dan pintu masuk dari lantai 1 menuju lantai 2 tidak berubah yaitu tetap pada $90^{\circ}$, dan palang pintu tidak menutup. Kemudian apabila terjadi kondisi lantai 1 terisi 5 buah kendaraan sedangkan lantai 2 terisi kurang dari 5 buah kendaraan, maka motor servo 1 dan motor servo 2 berada pada posisi $90^{\circ}$ dan kondisi kedua palang pintu tidak akan menutup.

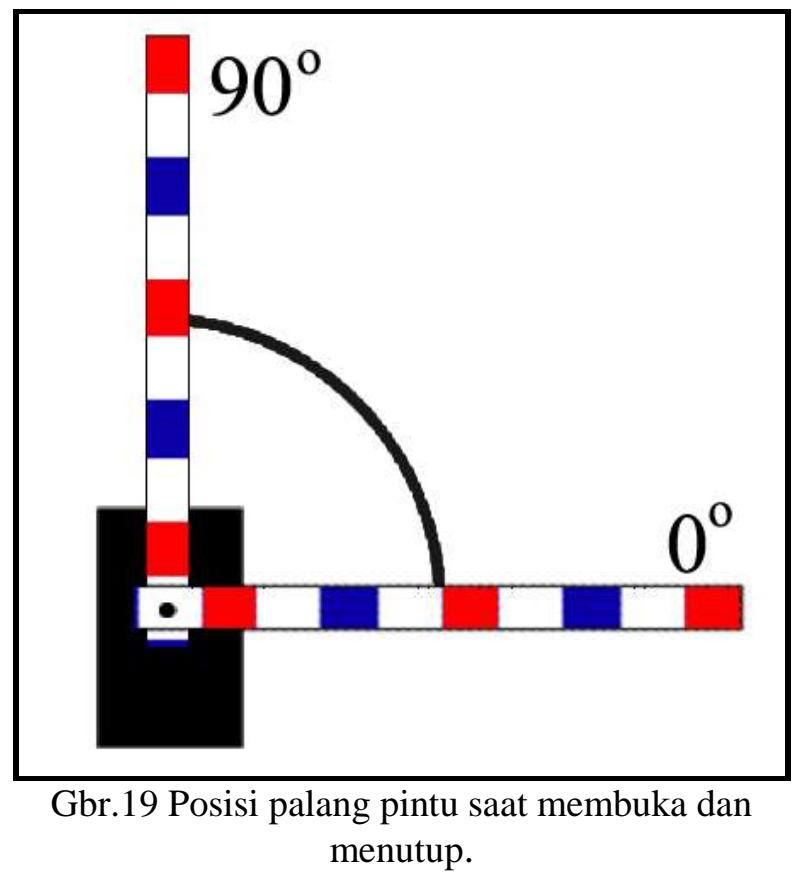

Tabel 6 Sampel data pengujian piranti dengan menggunakan mobil tamiya sebagai objek pindai.

\begin{tabular}{|c|c|l|l|l|l|}
\hline $\begin{array}{c}\text { Lantai } \\
1\end{array}$ & $\begin{array}{c}\text { Lantai } \\
2\end{array}$ & $\begin{array}{c}\text { Servo } \\
1\end{array}$ & $\begin{array}{c}\text { Servo } \\
2\end{array}$ & $\begin{array}{l}\text { LCD } \\
\text { Baris } \\
\text { Ke 1 }\end{array}$ & $\begin{array}{c}\text { LCD } \\
\text { Baris } \\
\text { Ke 2 }\end{array}$ \\
\hline 3 & 2 & $90^{0}$ & $90^{0}$ & Kosong 2 & Kosong 3 \\
5 & 0 & $90^{0}$ & $90^{0}$ & Penuh & Kosong 5 \\
4 & 0 & $90^{0}$ & $90^{0}$ & Kosong 1 & Kosong 5 \\
3 & 5 & $90^{0}$ & $0^{0}$ & Kosong 2 & Penuh \\
1 & 3 & $90^{0}$ & $90^{0}$ & Kosong 4 & Kosong 2 \\
0 & 2 & $90^{0}$ & $90^{0}$ & Kosong 5 & Kosong 3 \\
2 & 5 & $90^{0}$ & $0^{0}$ & Kosong 3 & $\begin{array}{l}\text { Penuh } \\
\text { Penuh }\end{array}$ \\
5 & 5 & $0^{0}$ & $0^{0}$ & Penuh & \\
\hline
\end{tabular}

Dari tabel terlihat pada data ke 1, saat di lantai 1 terdapat 3 buah kendaraan yang mengisi area parkir dan saat di lantai 2 terisi 2 buah kendaraan yang parkir, motor servo 1 dan motor servo 2 berada pada posisi $90^{\circ}$, sedangkan pada LCD tertera keterangan bahwa pada lantai 1 terdapat tempat kosong yang dapat diisi oleh 2 kendaraan yang dapat diparkirkan dan pada lantai 2 terdapat 3 tempat kosong yang dapat diisi oleh 3 kendaraan yang dapat diparkirkan.

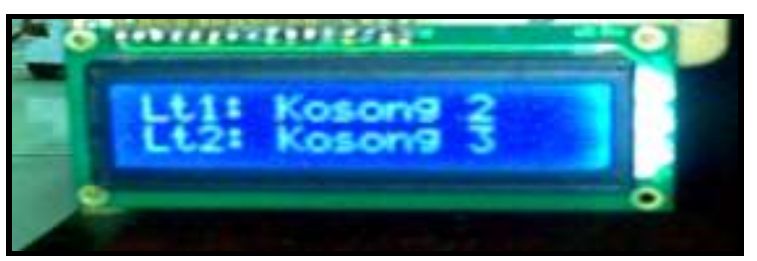

Gbr. 20 Tampilan LCD saat kondisi area parkir di lantai 1 terdapat 3 mobil yang parkir dan di lantai 2 terdapat 2 mobil yang parkir

Pada data ke 2, di lantai 1 terdapat 5 buah kendaraan yang mengisi area parkir dan di lantai 2 terisi 0 buah kendaraan yang parkir, motor servo 1 dan motor servo 2 berada pada posisi $90^{\circ}$, sedangkan pada LCD tertera keterangan bahwa pada lantai 1 parkir penuh 
sehingga tidak dapat diisi oleh kendaraan yang ingin diparkirkan dan pada lantai 2 terdapat 5 tempat kosong yang dapat diisi oleh kendaraan yang ingin diparkirkan.

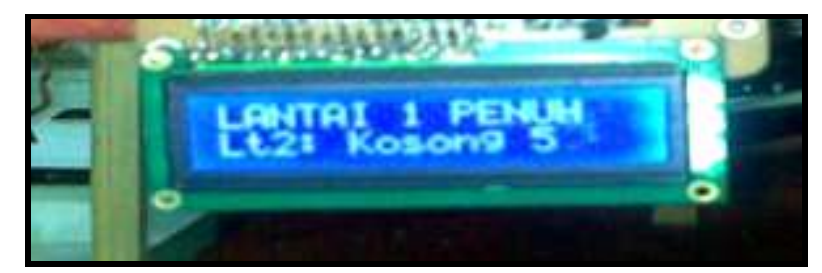

Gbr.21 Tampilan LCD saat kondisi area parkir di lantai 1 terdapat 5 mobil yang parkir dan di lantai 2 tidak ada mobil yang parkir.

Data ke 3 adalah saat di lantai 1 terdapat 4 buah kendaraan yang mengisi area parkir dan di lantai 2 terisi 0 buah kendaraan yang parkir, motor servo 1 dan motor servo 2 berada pada posisi $90^{\circ}$, sedangkan pada LCD tertera keterangan bahwa pada lantai 1 terdapat 1 tempat untuk parkir kendaraan dan pada lantai 2 terdapat 5 tempat kosong yang dapat diisi oleh kendaraan yang ingin diparkirkan.

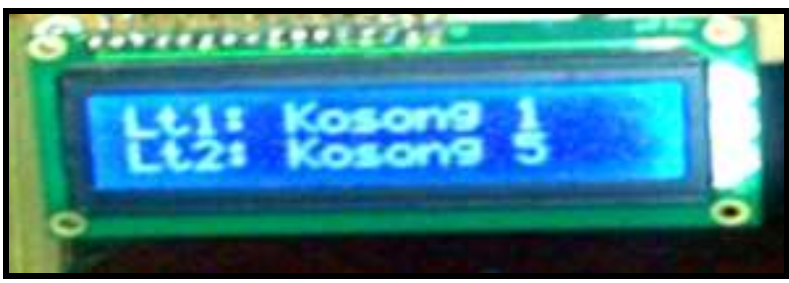

Gbr. 22 Tampilan LCD saat kondisi area parkir di lantai 1 terdapat 4 mobil yang parkir dan di lantai 2 tidak ada mobil yang parkir.

Data ke 4 merupakan saat lantai 1 diisi oleh 3 buah kendaraan dan lantai 2 diisi oleh 5 buah kendaraan, motor servo 1 berada pada posisi $90^{\circ}$ dan motor servo 2 berada pada posisi $0^{0}$ sehingga palang pintu dari lantai 1 menuju lantai 2 tertutup. Sedangkan pada LCD tertera keterangan bahwa di lantai 1 masih bisa diisi oleh 2 buah kendaraan lagi namun di lantai 2 tempat parkir sudah penuh.

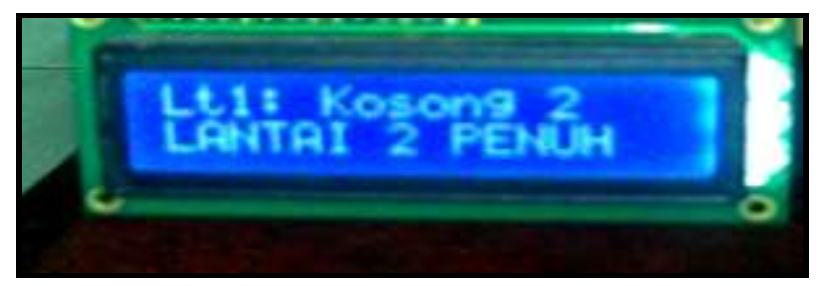

Gbr.23 Tampilan LCD saat kondisi area parkir di lantai 1 terdapat 3 mobil yang parkir dan di lantai 2 terdapat 5 mobil yang parkir.

Pada data ke 5, di lantai 1 terdapat 1 buah kendaraan yang mengisi area parkir dan di lantai 2 terisi 3 buah kendaraan yang parkir, motor servo 1 dan motor servo 2 berada pada posisi $90^{\circ}$, sedangkan pada LCD tertera keterangan bahwa pada lantai 1 terdapat 4 tempat yang dapat diisi kendaraan yang ingin diparkirkan dan pada lantai 2 terdapat 2 tempat kosong yang dapat diisi oleh kendaraan yang ingin diparkirkan.

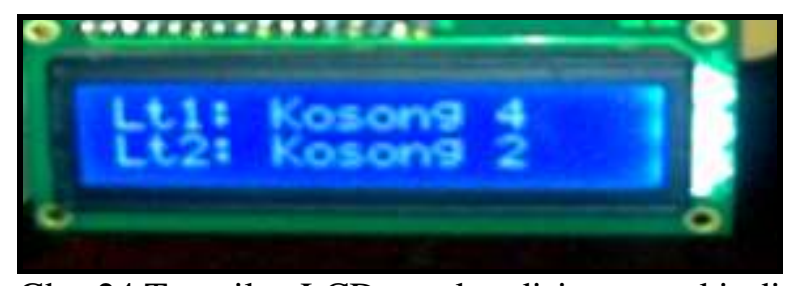

Gbr. 24 Tampilan LCD saat kondisi area parkir di lantai 1 terdapat 1 mobil yang parkir dan di lantai 2 terdapat 3 mobil yang parkir.

Data ke 6 adalah saat di lantai 1 tidak terdapat satupun kendaraan yang mengisi area parkir dan di lantai 2 terisi 2 buah kendaraan yang parkir, motor servo 1 dan motor servo 2 berada pada posisi $90^{\circ}$, sedangkan pada LCD tertera keterangan bahwa pada lantai 1 terdapat 5 tempat untuk parkir kendaraan dan pada lantai 2 terdapat 3 tempat kosong yang dapat diisi oleh kendaraan yang ingin diparkirkan.

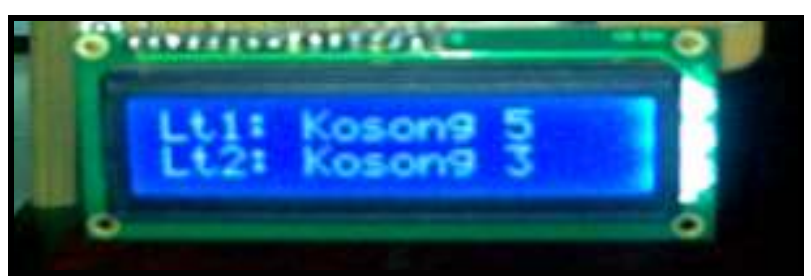

Gbr. 25 Tampilan LCD saat kondisi area parkir di lantai 1 tidak ada mobil yang parkir dan di lantai 2 terdapat 2 mobil yang parkir

Data ke 7 merupakan saat lantai 1 diisi oleh 2 buah kendaraan dan lantai 2 diisi oleh 5 buah kendaraan, motor servo 1 berada pada posisi $90^{\circ}$ dan motor servo 2 berada pada posisi $0^{\circ}$ sehingga palang pintu dari lantai 1 menuju lantai 2 tertutup. Sedangkan pada LCD tertera keterangan bahwa di lantai 1 masih bisa diisi oleh 3 buah kendaraan lagi namun di lantai 2 semua tempat parkir sudah terisi.

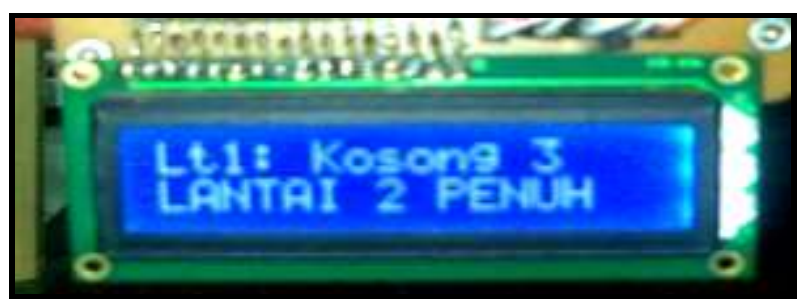

Gbr. 26 Tampilan LCD saat kondisi area parkir di lantai 1 terdapat 2 mobil yang parkir dan di lantai 2 terdapat 5 mobil yang parkir

Data ke 8 merupakan data terakhir, saat lantai 1 terisi penuh oleh kendaraan yang parkir dan lantai 2 pun demikian, motor servo 1 dan motor servo 2 berada pada posisi $0^{0}$ sehingga palang pintu utama dan palang pintu dari lantai 1 menuju lantai 2 dalam kondisi 
tertutup. Sedangkan pada LCD tertera keterangan bahwa di lantai 1 dan di lantai 2 tempat parkir sudah penuh.

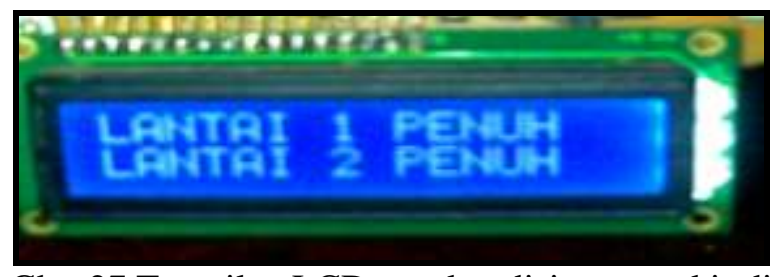

Gbr. 27 Tampilan LCD saat kondisi area parkir di lantai 1 terdapat 5 mobil yang parkir dan di lantai 2 terdapat 5 mobil yang parkir

Dalam mengeksekusi program, mikrokontroler membutuhkan waktu. Seperti pada saat memanggil sensor ultrasonik untuk bekerja apakah terdapat objek yang dipindai atau tidak. Sensor-sensor tersebut membutuhkan delay sebesar $10 \mathrm{~ms}$ untuk melakukan 1 kali pemindaian di setiap pintu. Artinya, dalam 1 detik terjadi proses 2,5 kali siklus pemindaian bila ada objek yang dipindai. Hal ini dimaksudkan agar semua objek dalam hal ini mobil/kendaraan roda 4 tanpa celah dapat dipindai apabila sama-sama melewati pintu-pintu tersebut.

\section{KESIMPULAN}

1. Rancang bangun model sistem penghitung kendaraan pada area parkir ini merupakan piranti otomatis yang dapat mengontrol jumlah kendaraan yang masuk dan keluar pada area parkir.

2. Sensor ultrasonik yang digunakan merupakan sensor ultrasonik jenis ping dengan metode time of flight yang memiliki tingkat akurasi rendah saat memindai objek pada jarak $3 \mathrm{~cm}$ atau kurang.

3. Mikrokontroler tidak mengeksekusi program secara bersamaan, dibutuhkan delay dalam hitungan $\mathrm{ms}$ atau $\mu \mathrm{s}$ untuk menjalankan perintah kepada setiap komponen yang terhubung dengan mikrokontroler.

4. Mikrokontroler memberi perintah kepada sensor ultrasonik, LCD, motor servo, serta menyimpan data jumlah kendaraan di lantai 1 pada R16 dan data jumlah kendaraan di lantai 2 pada R17, sehingga pada saat jumlah kendaraan di R16 dan R17 hampir penuh, mikrokontroler membutuhkan delay hampir 1 detik untuk memberikan perintah kepada sensor ultrasonik, sehingga kinerja piranti menjadi lebih lambat dari yang diharapkan.
[1] Budiharto, W dan Rizal, G. 2006. 12 Proyek Mikrokontroler untuk Pemula. Jakarta: Elex Media Komputindo.

[2] Hermansyah. 2008. Dispenser Otomatis. Universitas Lampung. Bandar Lampung.

[3] Huda, S. 2008. Rancang Bangun Kendali Posisi Robot Beroda Dengan Pengendali Logika Fuzzy Menggunakan Sensor Jarak Ultrasonik. Universitas Lampung. Bandar Lampung.

[4] Listiono. 2004. Pengontrolan Kapasitas Parkir Mobil Menggunakan Komputer Berdasarkan Kerja Programmable Logic Controllers. Perguruan Tinggi Mitra Lampung. Bandar Lampung.

[5] Wardhana, L. 2006. Belajar Sendiri Mikrokontroler AVR Seri ATMega8535 Simulasi, Hardware, dan Aplikasi. Yogyakarta: Andi.

[6] Wobschall, D.1987.Circuit Design for Electronic Instrumentation. United States: McGraw-Hill.

\section{REFERENSI}

